\title{
THE POLITICAL ICONOLOGY OF THE INDONESIAN POSTAGE STAMP (1950-1970)
}

\author{
Jacques Leclerc
}

\section{Working hypotheses}

1.1 The starting point of our investigation is the fact that the issuing of postage stamps is at once the issuing of images and of images controlled by the State through the intermediary of special commissions of the postal service. At the same time, it must be kept in mind that the iconic function of the stamp is, in principle, subordinate to the fiscal function, which privileges face value, that is the amount of the tax which, when affixed to the piece of mail, can be collected.

The image and the franking value can also be presented as an illustration reduced to the figure(s) expressing this value: such is the case of the Indonesian "post paid" (bajar porto) stamps. But even in this extreme case, the colors of the stamp and the design of the figures add an aesthetic level to the fiscal information.

At the other end of the scale, certain issues are less concerned with the necessities of franking than with the potential philatelic market: moreover, the face value of the stamp is often defaced by a surtax, the resulting sum being, in fact, the sales price of a certain type of picture. Even though collectors are not motivated primarily by the elegance of the image, stamps for collectors often fall back on internationally established iconography, something I would call the "scenic" stamp: flowers, butterflies, birds, landscapes, various oddities, and particularly touristic sites. The Indonesian postal service addressed stamp collectors as early as 1949 with its first-day cancellations; first-day covers appeared in 1954 and, in 1961, firstday sheets, featuring, significantly enough, a set of ten stamps promoting tourism.

\footnotetext{
The French version of this article appeared in Archipel 6 (1973): 145-83. The author would like to express his gratitude to the Fondation Nationale des Sciences Politiques and to the Centre d'Etudes et de Recherches Internationales for funding the translation of this article, as well to the translator, Nora Scott, who has done more than simply translate.
} 
That scenic stamps often bear a surtax is justified by the fact that they are issued for the benefit of what are called charitable or "social" concerns. But behind such a justification, which in fact takes refuge behind the image from the social reality it claims to be easing by the surtax, lies nothing but the fashionable superficiality typical, in the Western World at least, of charity drives. Of the eleven sets issued between 1960 and 1970 to celebrate Hari Sosial, the annual "Social Works Day," only two (1960 and 1967) referred to social themes; the others featured, in order: fruit, orchids, butterflies, birds, flowers again, reptiles, more fruit, sea shells, insects; "Social Works Day" seems to have been more the occasion than the reason for their issue.

In view of the difference in levels of iconic signification from one set to the next, we wondered if it might not be possible, by examining a sequence covering a relatively long span of time (20 years), to single out a number of elements and tendencies constituting what might be called "an official mental picture."

1.2 Our starting point is 1950 (constitutionally speaking: August 15, 1950, two days before the fifth anniversary of the proclamation of Indonesian independence), when Indonesia inaugurated its history as one republic, indivisible, liberated from foreign occupation (which had lasted well beyond the proclamation of independence into the early days of 1950). The edification of a unified State as well as the generalization of national feeling demanded an intense ideological activity on the part of State authorities; they needed to define their cultural specificity and provide the country with socio-historical references that would enable others to identify it. These could be embodied or reactivated in the collective consciousness by such events as commemorations and national holidays, the outline and signals of a differentiated practice of economic and political development.

The broad lines of this practice can be condensed into a form of official ideology, by which I mean an ideology officially described and taught as such, which was to emerge, effectively and with more or less force, at the end of the 1950s. The diffusion of this ideology, in the general course of the circulation of ideas, led to systematic State intervention. Are these potential elements of an "official mental picture" which, for example, finds its public formulations in the early 1960 s under the name of indoktrinasi? For which commemorations and for which memories are Indonesian stamps in reality the channel or the locus? Of what chronicle, of what history-past, future, or only dreamed-were they, on their level, to be the "picture strip," to borrow a term from the movie world? To what image of Indonesia did they contribute?

\section{Sources}

\subsection{In our search for answers we used the following:}

\subsubsection{Catalogues:}

Katalogus dari Perangko Perangko Republik Indonesia, Surabaja, Popular, 1967 (stamps issued from December 1948 to May 1966);

Catalogus van de Postzegels der Republik Indonesia, Amsterdam, Zonnebloem, 1972 (stamps from 1943 to December 1970).

These catalogues contain reproductions (nearly complete in the Popular catalogue, larger gaps in the Zonnebloem), authors (with a number of discrepancies between the two sources), date of issue and (in the Popular catalogue only) date of withdrawal, perforation, and where the images were printed. 
2.1.2 A collection containing approximately 90 percent of the stamps studied.

2.2 This material allows only an initial approach to the problems mentioned, however, in that the images are described, but not the conditions surrounding their selection.

2.2.1 The conditions preceding the issue are: the political, fiscal, aesthetic, and technical justifications for producing the stamp, no doubt formulated in the discussions of the committee entrusted with the program of releases, the minutes of which can theoretically be found in the archives of the postal service headquarters in Bandung (not forgetting the interventions and general guidelines of the Union Postale Universelle-we have been unable to ascertain whether the headquarters in Bern keeps a record of these). These justifications articulate the design/format/color/face value/print run complex, each component of which modulates the signification of the stamp and the way it is perceived by the user.

2.2.2 Following the issue, the terms are: the conditions of diffusion, supported by sociological statistics on the users: which stamps have the largest diffusion? which are most used? by whom? who writes (and receives) letters? and consequently sees the stamps? who collects them? etc.

2.3 It is for lack of such important details-the author would be grateful for any help in gathering such details-that the present investigation is entitled "iconology" and not "ideology" of the Indonesian postage stamp.

\section{Displaying the Image}

3.1 Aside from the bajar porto stamps and those restricted to parts of Indonesia endowed with a special political or fiscal status (Riau: stamps that circulate throughout the rest of Indonesia, but with a "Riau" surtax; Irian Barat: from 1963-1968, ordinary stamps endorsed "Irian Barat" and a special face value; from 1968-1970, separate stamps), 382 images were issued, between August 17, 1950 and December 31, 1970, which, counting the various face values of a single image, came to 617 different stamps or an annual average on the order of 20 images/30 stamps, attained in 1960 . (See fig. 1, A. The solid lines represent the total number of images issued each year, the broken lines represent the face values).

3.2 The graph shows an overall rise in the number of stamps issued, increasing regularly from 1952 to 1958 , irregularly from 1959 to 1970, peaking between 1961 and 1967, with the high in 1962.

3.2.1 This trend cannot be fully explained by the development of the postal service, the growing volume of mail, the diversification of postal rates, and their modification in respect of currency changes. A limited number of designs, even as few as one, given a broad enough range of face values and a high enough run, would be enough to satisfy such needs: that was, in fact, the case in 1951 with the issue of the sets that were gradually to replace those in circulation before the proclamation of the Unitary Republic, on August 15, 1950, a reality subsequently reiterated on the stamps by the imprint REPUBLIK INDONESIA, which appeared for the first time since 1947: a total of 40 face values for five images.

3.2.2 But the constitutional reference to the Unitary State implied in the words Republik Indonesia reinforced in the largest set (15 face values) by the image, directly inherited from Dutch usage, of the head of State, in this case President Sukarno, gives the revenue band the weight of a political statement.

3.2.3 This is confirmed by the fact that part of the Sukarno set would be printed as the inaugural run of the Kebayoran printing house, the first Indonesian printing works for 
stamps. This printing was purely symbolic on several levels, however, since the printing house would not be in full operation and able to cover Indonesia's needs in stamps until 1956-57; the rest of the 1951 Sukarno set had to be printed in Haarlem, in the former "mother" country.

3.3 The variety of Indonesian stamps is explained rather by the variety of functions they fulfill and the need to renew them, something certainly not peculiar to Indonesia: that the philatelic practice of "first-day cancellations" was introduced in 1949, on the occasion of the 75th anniversary of the Union Postale Universelle, with a commemorative stamp is a measure of its international character.

It is the growing capacity of Indonesia's stamp industry to respond to these manifold extant functions that explains the increase in the number of issues themselves. This capacity is confirmed not only by the opening of the Kebayoran printing house, but by the fact that, as early as 1950, Indonesian stamps were designed by national artists, maquettistes, and engravers, working on commission or full time, whom the postal service of Indonesia, unlike so many other newly decolonized countries that ordered their stamps from specialized international agencies or from the ex-colonial power, was able to recruit.

3.4 Figure $1 \mathrm{E}$ shows this recruitment, as well as the periods of activity of the nine artists most frequently used:

$\begin{array}{ll}1 & \text { Amat bin Djupri } \\ 2 & \text { Junalies } \\ 3 & \text { K. Risman Suplanto } \\ 4-7 & \text { (in alphabetical order) Kartono J., Mahriajub, S. Sumarsono/ Suwarsono, }{ }^{1} \text { Suroso } \\ 8 & \text { Sudirno } \\ 9 & \text { Suripto }\end{array}$

3.5 The role of the maquettiste seemed destined to grow apace, if the tendency visible in the graphs beginning in 1967 to start attributing a single face value per image was maintained: for example, since 1969, the standard set used for ordinary franking was a set of 10 different vignettes illustrating the goals of the five-year development plan, which replaced a set, issued two and a half years earlier, of 16 stamps each showing a different traditional musical instrument. This type of standard set took the place of those comprising a large range of face values for a single image (President Sukarno, whence the obviously political rather than technical reason behind their withdrawal), clearly indicated by graphs A and B $(1951,1965,1966)$.

3.6 It is difficult to measure the precise impact of each artist or team of artists on the program and the aesthetics of stamp production; all that can be shown are trends.

3.6.1 A gradual shift may be observed away from the descriptive, easily read subject picture toward geometric stylization, symbolic representations, and what might be called heraldic attempts at coats of arms (returning to what we said in 1.1 concerning the naturalist decor of surtax stamps: nature is the coat of arms of the social sphere), at signs (in correlation with international poster and billboard art), that is, at an apparently arbitrary system of figuration representing the programmed occasion of the stamp's issue (a sign which is sometimes imposed by the worldwide character of the occasion: a "day" designated by the

\footnotetext{
1 The catalogues we consulted mention S. Sumarsono, from September 1961 to December 1965, and then, from December 1966, Suwarsono. The possible disappearance of Sumarsono in 1966, a deadly year if ever there was, is less unlikely than the coincidence of the consecutive names.
} 
Figure 1

A Number of stamps issued annually: total number of different images and face values. (1) In the absence of adequate information, we attributed to 1951 the 15 small Sukarno figures, some of which did not appear until 1953.

B-E Search for areas of dominant significations. Graph B shows the wide discrepancy, in 1966, between the number of images issued (solid line) and the face values in the Sukarno set-issued in 1964 to replace the 1951 set-following the devaluation of the rupiah: to the 10 stamps issued in 1964 were added 6 more, overprinted 65, in new currency, then 20 in 1966, and one in 1967, before Sukarno's ouster in the same year made it necessary to withdraw the entire set; furthermore, in 1965 the same image was issued, overprinted conefo (Conference of the New Emerging Forces, being planned at the time), making a total of 52 different values for the same stamp design. Graph E: The short vertical lines of graph E show-in numbers of images, not values-the stamps that represent a postal event, including themselves (e.g. the stamp honoring the Centenary of the Indonesian postage stamp, see pl. I).

For the artists' names, see 3.4. For analysis of the graphs, see 3.1, 3.2, 3.7.1.
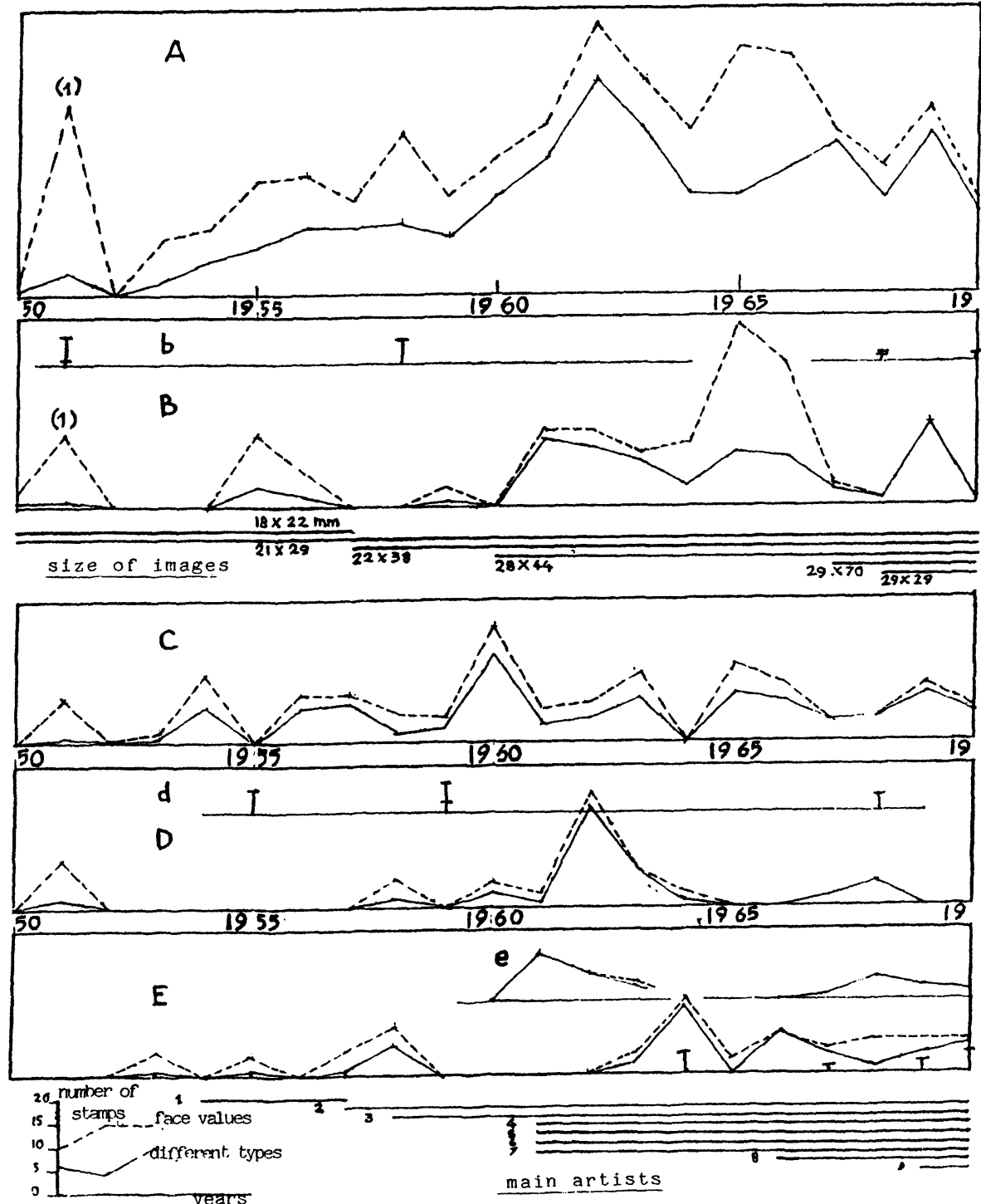
UN or by one of its agencies, UNESCO, WHO, FAO, and signified by an internationally fixed and diffused image which is also internationally decodable).

3.6.2 The period from 1954 to 1958 , for example, was characterized by sets of "typical scenes" on surtax stamps devoted to social concerns (1954: children; 1956: the blind; 1957: the physically handicapped; 1958: orphans), a genre in which Amat bin Djupri excelled, unlike the rather poor "stylizations" he would deliver when the commission had to do with a commemoration (1955: 10th anniversary of "Heroes' Day"; 1956: "Cooperation Day"), a genre in which Junalies, recruited in 1957, felt more at ease.

After 1957-58, "typical scenes" were relegated to the "post card" stamp and sets of picturesque scenes promoting tourism. Arbitrary signs, symbols, objects, and landscapes eliminated the "slice of life."

3.6.3 But more revealing than this evolution are the crises that punctuate it. One at least, in $1967-68$, is reflected in the violent dramatization of the figure/color/format complex.

Violent subjects: in October 1967, two stamps were issued of "wild animals fighting," by the painter Raden Saleh Sarif Bustaman (1813-1880) without any particular reason for honoring him, no anniversary being near; in December 1967, the annual "Social Works Day" set forsook the usual flowers and butterflies for catastrophes: a flood, landslide, conflagration, volcanic eruption; violence was evoked as well with the issuing, on August 17, 1967, the national holiday, of three scenes showing the maquette of the colossal monument raised around the well at Lubang Buaya, into which, on October 1, 1965, the bodies of the officers executed by the Untung group were thrown and which had become the site of a pilgrimage, thus determining the origin, center, and sanctuary of the new power, the founding sacrifice.

Hypertrophy and sophistication of new formats (cf. fig.1B chronology of formats): one $29 \times 70$ mm image (July 1967: International Tourism Year; June 1968: Scout Camp), that tears into 3 separate stamps corresponding to a $21 \times 29 \mathrm{~mm}$ format, even though the three form a continuous picture (March 1968: Borobudur). The same process of splitting was subsequently used in the $29 \times 44 \mathrm{~mm}$ format already in circulation for some time (October 1968: Mexico City Olympic Games).

Use of loud colors: The mixing of loud colors, previously not practiced, is sometimes linked to the $29 \times 70 \mathrm{~mm}$ format; it takes over such thematically different issues as those devoted to tourism (1967, 1968) or "Aviation Day" (April, 1967).

3.6.4 Whereas any one of these elements is not significant in itself, the emphatic treatment of typical scenes (even reproductions of works of a painter or sculptor, that is of a monument outside the postal service), acquires as a series the value of testimony, the transfer, through the sharpening of certain iconic signs of a national and/or individual trauma, an unplayed tragedy, an unprogrammed occasion, even if the break, the will to instigate a figurative revival was intentional.

By 1969 the crisis had apparently subsided, the use of many colors was relegated to the annual set promoting tourism, and once again armories prevailed.

3.7 The catalogue makes it simple enough to construct graph A, with all the types and values issued between 1950 and 1970, but using it to construct graphs, each of which brings together homogeneous semantic sets, so that the sum of these partial graphs tends to reproduce $A$, confronts us with the complexity and multiplicity of the conscious and unconscious means embodied in the stamp as a visible sign. 
3.7.1 Although there was some initial arbitrariness in the classification, which we hope to reduce later in this article, we have, within the general field of a dominant meaning whose function is political (by political we mean anything that implies a short-term relation to the governing of people), narrowed the possibilities down to four preferential areas, shown respectively in graphs $B / b, C, D / d, E / e$ :

$B$ Commemoration of struggles for independence, institutions, portraits of the head of State, development plans, the Bandung Conference and Afro-Asian solidarity (in $b$ : international integration institutionalized by the UN), roughly speaking what is announced by the Indonesian concepts : kebangsaan, kedaulatan rakyat, and perikemanusiaan (see 4.1.4).

C Social solidarity, safety, and justice (with the exception of development plans), which cover images concerning food, housing, health, education, better working conditions, including images commemorating International theme days (declared by the FAO, WHO, UNESCO, ILO): graph C is punctuated by special Bentjana Alam (natural disaster) surtax issues: 1953, flooding in Aceh; 1954, eruption of Mount Merapi; 1961, various disasters; 1963, eruption of Gunung Agung; 1966, Solo River flood; and from 1960, the annual commemoration of Hari Sosial (it does not appear on the graph for 1964 because it was celebrated late, in 1965); in 1967, the two themes coincided: the Hari Sosial set was devoted to Bentjana Alam (see above 3.6.3).

D Sporting events: every three years, from 1958 to 1967 , there was an issue celebrating the world championship Thomas Cup for badminton (bulutangkis), held during that period by Indonesia, but the outstanding feature is the ballooning of the number of values issued in 1962-63 (32 out of a total 66 values for the entire graph), which bears witness to a quantitative and perhaps even qualitative change in the functions connected until then with such events and their commemoration by stamps (we have plotted on the graph all types of stamps marked "ASIAN GAMES IV DIAKARTA 1962" and "GAMES OF THE NEW EMERGING FORCES DJAKARTA NOVEMBER 10-22 1963, , even if the image did not show a sport, players, or the playing field); $d$ shows the fairly related field of scouting.

$E$ Communications, transportation, and meeting places (other than those dealt with previously, political halls, sports stadia...) post office, bank, international expositions (including those promoting tourism, which have been grouped together on graph e). The postal service makes generous use of these stamps to diffuse the image it wants to give of itself: graph E shows nothing but the post, in fact, until the end of 1957; moreover, the first public building shown on an Indonesian stamp was, in January 1953, the main post office in Bandung, and the first head, other than that of the President of the Republic, was, in September 1955 for the 10th anniversary of the Indonesian postal service, that of its first director: narcissism of the center and the head which encloses and freezes into a State within a State a service whose raison $d^{\prime}$ être is the creation of links between people and the circulation of information, openness and exchange, and therefore mobility. It was not really until 1964 that a set of 12 figures by Suroso merged the postal service with the other means of transportation, which he showed being operated, that is, by postal employees (mail carriers, switchboard operators, teletypists) working in the midst of a complex of vehicles, both traditional and new, air mail, sea mail (also commemorated by special issues in $1958,1964,1966,1967,1969$, but perhaps less as means of transportation than as signs of prestige and modernity) restored here to their original calling as a public service, an 
authoritative instrument for measuring, appropriating, and unifying the national space.

3.7.2 Here we can state conclusively that the four areas-no stamp having been included in more than one graph-work together and that this very fact points to one of the dimensions of the mental picture under investigation.

\section{Institutional Coats of Arms}

4.1 The choice of August 17 as the issue date for new stamps is an affirmation on the part of the postal service of the political significance of stamps as commemorating the act that legally founded the Indonesian State, the proclamation of independence on August 17, 1945.

4.1.1 The catalogue of these stamps is as follows (see fig. 2)

Figure 2

\begin{tabular}{|c|c|c|}
\hline Year & $\begin{array}{l}\text { Commemoration } \\
\text { indicated on stamp }\end{array}$ & Description of figure \\
\hline 1950 & 5th anniversary of Independence & arms of the Republic \\
\hline 1955 & 10th anniversary & $\begin{array}{l}\text { grouping of } 3 \text { classic figures from August } 17,1945 \text { : } \\
\text { Sukarno, Hatta on his left reading the Proclamation, } \\
\text { Sukarno and Hatta at first raising of the flag; } \\
\text { reproduction of manuscript of the Proclamation }\end{array}$ \\
\hline 1959 & $\begin{array}{l}\text { "Restoration of the } 1945 \\
\text { constitution" } \\
\text { (KEMBALI KE UUD 1945) }\end{array}$ & text in Sukarno's handwriting \\
\hline 1960 & & $\begin{array}{l}\text { set of } 8 \text { stamps showing hasil bumi (fruits of the land), } \\
\text { from the smallest to the largest face value: oil palm, } \\
\text { sugar cane, coffee bush, tobacco, tea bushes, coconut } \\
\text { palm, hevea, rice }\end{array}$ \\
\hline 1961 & & first set of pahlawan (national heroes) \\
\hline 1965 & $1945-1965$ & $\begin{array}{l}5 \text { stamps featuring the Panca Sila ( } 5 \text { principles) set out } \\
\text { by Sukarno on June 1, 1945, represented by their } \\
\text { symbol on the arms of Indonesia (cf. stamp issued } \\
\text { August } 17,1950 \text { ) }\end{array}$ \\
\hline 1967 & $\begin{array}{l}\text { MONUMEN PAHLAWAN REVOLUSI } \\
\text { LUBANG BUAJA, } 1 \text { OKT. } 1965\end{array}$ & $\begin{array}{l}\text { presentation in } 3 \text { stamps of the maquette of the } \\
\text { monument to those who died on Oct. 1, } 1965 \text { (see } \\
\text { above 3.6.3) }\end{array}$ \\
\hline 1969 & $\begin{array}{l}\text { PELITA (Pembangunan Lima Tahun): } 5 \text { - } \\
\text { year development }\end{array}$ & $\begin{array}{l}\text { a set of } 10 \text { figures illustrating the goals of the five- } \\
\text { year development plan just adopted }\end{array}$ \\
\hline 1970 & a quarter century of Independence & an obelisk-shaped design \\
\hline
\end{tabular}


4.1.2 Only three of these issues actually claim to commemorate the event-in 1950, 1955, and 1970. The evolution of their iconography, from the 1955 reproduction of photographs of the August 1945 ceremonies to the symbolic obelisk on the 1970 stamp, (see pl. VI) seems to confirm the transition, already mentioned, from description to abstraction.

The function of the other issues is, then, to integrate directly into the memory of independence, as consubstantial elements, figures which no longer project the moment of the Proclamation but now proclaim the conditions, either institutional $(1959,1965,1967)$ or economic (1960,1969), for achieving and preserving the declared independence.

4.1.3 An important anniversary, the dwiwind $u$ (twice eight years), of the Proclamation was celebrated, but the commemorative set anticipated the date and appeared on July 6, 1961 (see pl. VII, lower right). The image is made up of two elements: on the left, a stylized drawing of modern buildings and factory smoke stacks, which can be identified from other figurative contexts (set XI, Conference of the Colombo Plan Countries, 1959; Census, 1961; Regional Family Planning Conference, 1969 ...) as a sign of production and economic development; on the right, a group of three silhouettes differentiated only by their headgear (a pici, a conical hat, and a hard hat), carrying a beam on their shoulders, symbol of the team work, gotong-royong that, since his 1926 article, "Nationalisme, Islamisme dan Marxisme," on the three ideological components of the Indonesian national movement, Sukarno never tired of invoking. The "all together, heave-ho!" "ho-lopis-kuntul-baris," of the June 1, 1945 speech, and the call for tritunggal, for the convergence of these three tendencies to shoulder Indonesia's burden, punctuated the speech, which in its ternary title, "Revolusi Sosialisme Pimpinan" (RESOPIM), commemorates this dwiwindu.

4.1.4 It was to mark the 20th anniversary of the June 1, 1945 speech, the one which formulated the Panca Sila, the five principles of national unity, alat pemersat $u$... bukan alat pemetjahbelah, "instrument of unity, not division," as its author recalled in RESOPIM, August 17, 1961-and which would subsequently be condensed into gotong-royong-that five stamps were issued on August 17, 1965 (and not June 1). The sharply differentiated face values of these stamps place the principles described in a hierarchical order :

Figure 3

\begin{tabular}{|c|c|}
\hline $\begin{array}{c}\text { Face value } \\
\text { (tax + surtax, in rupiah) }\end{array}$ & $\begin{array}{c}\text { Principle } \\
\text { (as featured on the stamps) }\end{array}$ \\
\hline $10+5$ & $\begin{array}{c}\text { KEADLAN SOSIAL } \\
\text { social justice } \\
\text { PERIKEMANUSIAAN } \\
\text { humanitarianism } \\
\text { KEBANGSAAN } \\
\text { national unity } \\
\text { KEDAULATAN RAKJAT } \\
\text { Sovereignty of the people } \\
40+15\end{array} 50+15$ \\
KETUHANAN JANG MAHA ESA \\
belief in one God
\end{tabular}


This vertical listing of the Panca Sila, God first and social justice last (the order of the other principles is not rigid, and Perikemanusiaan can just as well be exchanged with Kedaulatan Rakjat), represented, from the outset, a challenge to the horizontal conception preferred particularly by the Communists and Sukarno, and which a few months later was officially to prevail.

4.1.5 Thus the axis of the obelisk (1970) rises in the space symbolically delineated by the arms of the nation (1950): it recapitulates twenty-five years of history. All that went beforethe "heroes" portraits (in 1961) are concerned with history itself, the history that grounded the 17th of August and which is punctuated by its annual commemoration-can be read in two trajectories: that of the institutional legitimacy of political power and that of its confirmation by economic growth, which are linked by the images of the nation, the constitutional source of power, at work, the economic justification of the political order that designs the basic axis.

If, in 1961, the issue was to establish a link between the proclamation of independence and those who prepared it, the commemoration of the proclamation being divided between two dates, July 6 and August 17, in order that it might be understood on the two levels of meaning attributed to it, in 1959 and 1967 the issue was to integrate institutional discontinuities into the anniversary of the Republic, that is, into the historical continuity of the country, and to present them as a return to the origins, a return to August 17. That was the slogan that justified the abrogation, on July 5, 1959, of the provisional constitution of August 15, 1950: KEMBALI KE UUD 1945, "restoration of the 1945 constitution," and it was also the slogan that appeared on the stamp issued August 17, 1959, because the July 5th slogan could not symbolically take effect on any day other than August 17, this particular August 17, 1959, which was also the day Sukarno pronounced his Political Manifesto, the founding text of "Guided Democracy." The same preoccupation with legitimation was evident in the homage paid to those who died on October 1, 1965 with stamps issued on August 17, 1967, as General Suharto had just been declared President of the Republic of Indonesia, replacing the ousted Sukarno, and was the one now speaking for the State.

4.2 In its heraldic pictogram form (padi-kapas, an ear of rice, a branch of cotton, metaphor for the slogan sandang-pangan [food and clothing] used as the basic reference for "standard of living,") keadilan sosial "social justice" is relegated, in the 1965 set, to the lower ranks of the five principles. Nevertheless, it is the only one that circulates so visibly outside the coat of arms of the State, entering into the composition of other armories (the Military Academy, 1968; the Railroad, 1968; Justice, 1970; the Post Office, 1970) or into occasional insignia (10th anniversary of the Bandung Conference, 1965). All are external emblems that the stamp merely diffuses, but they also comprise an isolable unit of specific iconic utterances symbolizing projects of a social (Hari Kooperasi, 1957; Hari Sosial, 1960) or an economic nature (for instance, the 11th Conference of Colombo Plan Countries and the Regional Family Planning Conference already mentioned, in which, in contrast to images of industry and transportation, these are more closely identified with agriculture alone, and in which, among the industrial images, the construction trades now add to the basic requirement of food and clothing expressed by padi-kapas, that of housing). But it appeared first and foremost in 1951, as the only picture frame out of a set of nine values, the first of this importance after the restoration of the Unitary Republic, a historic priority, then, and one capable of bringing the economic and social spheres together in the armories of institutions and programs (pl. VII). 


\section{Identifying the Space}

5.1 The Asian Games, under the aegis of the International Olympic Committee, were held for the first time in 1951, in New Delhi. For the occasion, Indonesia's postal service issued a small single-colored stamp, in five face values, bearing a map of South and Southeast Asia ; the Olympic torch marked New Delhi, and Indonesia was designated by the Borobudur stupa, the entire design being overprinted with the five Olympic rings.

The Fourth Asian Games were held in Jakarta and began, in the huge sporting complex that had just been completed, on August 24, 1962. Exactly five months before, on March 24, the first set of stamps announcing the Games appeared. Their format ( $28 \times 44 \mathrm{~mm})$ was recent and at that time used almost exclusively for ceremonial occasions: it was inaugurated in February 1961, featuring President Sukarno holding a hoe, to celebrate the launching of a new national development plan; it was not seen again until January 1962, bearing six figures from the Ramayana in front of Siva's temple in Prambanan, then in February with the maquette of the Mosque of Independence in Jakarta, the construction of which had just begun. The March 1962 release, with a salvo of four stamps of different values but all carrying the single figure of an archer, a Javanese sculpture from the classical period, encompasses the gaze in the great tradition of royal culture, ${ }^{2}$ which brings together worship and the State into great festive gatherings and, from the outset, diffuses one possible meaning of the approaching Games.

5.2 In one of his books on Romanesque art in west-central France, René Crozet, comparing the frescoes of churches between the rivers Loire and Cher, makes a passing contrast between the "large symbolic figures" of the first and the "narrative style" of the others. ${ }^{3}$ In the same manner, we might contrast the two sporting events reproduced on and by the 1958 stamps: the Thomas Cup, that the Indonesian Men's Badminton team won for the first time at the Triennial Championships held that year in Singapore (in 1961 they were held in Jakarta, in one of the first-completed buildings of the architectural complex built for the Fourth Asian Games: the stamp issued for this occasion featured not only the cup, but where it was won), and the first (and only) Tour de Java.

\subsubsection{Karunia Tuhan Jang Maha Esa Berkat Doa Restu Seluruh Bangsa}

This formula of thanksgiving ("Thanks be to God and to the prayers of the whole nation"), inscribed on the 1964 stamp, presenting the Thomas Cup beribboned in the colors of Indonesia, confirms the competition as both liturgy and ordeal; the stamp is an ex-voto of the winning team, itself the image of and model for the "whole nation." When the stamp came out, like the final sky rocket of a fireworks display, it had been three months since the athletes who had won the Thomas Cup for the third time in a row had been officially received by the head of State and paraded triumphantly, like astronauts in other countries, through the streets of Jakarta lined with giant murals in preparation for the nineteenth anniversary of the Panca Sila. ${ }^{4}$

\footnotetext{
2 I give the term "great tradition" the same general meaning as Robert Redfield in his Peasant Society and Culture (Chicago, 1956), ch. 3.

3 René Crozet, L'Art roman en France, bassin de la Loire et Ouest (Paris, 1961), p. 22.

4 See Indonesia, vol iv, pp. 117-23, chapter "World Champions Three Times Over" (Indonesia was published yearly, in English, as an international platform for the Indonesian Ministry of Foreign Affairs):

"I. . . ] To the Republic of Indonesia, sports are a useful vehicle for building a nation out of a people oppressed for centuries.
} 
In 1967 Indonesia became world champion for the fourth (and last) time in a row: while one of the stamps issued marks, with a drawing of the four cups, the rhythm and continuity of the victories, the other indicates the scope: the trophy is shown against a globe of the world-the sign of temporal but also royal power.

5.2.2 Because it was run from August 17 to 30, the 1958 Tour de Java was an extension of the National Independence celebrations; and it was even more of a celebration of national unity that year inasmuch as, in February, a rebel government had been proclaimed in Padang, backed by peripheral guerrillas in Sulawesi and Maluku.

And yet the maquettiste K.R. Suplanto (author of the Thomas Cup sets of 1958, 1961, and 1964) chose to devote the entire rectangle of the stamp to a map of Indonesia, and, using the French version, Tour de Java I 1958, superimposed a speeding racer, his bicycle astride the island of Java, which seems to be drawn on the plane the man is crossing (cf. pl. III).

This graphic solution begs the political question of Java's relationship to Indonesia-is it syntagmatic (Java as part of Indonesia and proposed as such) or paradigmatic (the part, Java, as a metaphor for the whole, Indonesia) -for it cannot in fact respond to the ambiguous meaning of a circuit.

Ambiguity both technical and political, then.

The Archipelago of a thousand islands is not a good candidate for a bicycle circuit, for the narrative continuity of a race. Moreover, as a survey of the domain, a tour of the possessions, which redistributes along the route the excitement elsewhere concentrated in stadiums, the Tour also traces the outline imposed by the course of the race, showing up the weaknesses and deficiencies, the clearings and routes to be opened if the whole Archipelago is to be encompassed: Java alone appears to be served. As the stamp shows, what is drawn as Indonesia, is restricted to what is called Java.

But to call Java by name in this way, whatever may be the meanings with which the sign Java is and will be invested, because at the same time attempts at establishing centrifugal poles-or even counter-centers-are going on in the periphery, is to formulate a doubly false statement which excludes the unstable periphery from the domain and recognizes its secession: it is a technical dodge which runs the risk of formulating a political defeat, whereas there is need both to display and to assert the totality and the center, the totality in its center.

5.2.3 The "sports" stamps for 1958 placed two things on trial, then: the Cup and the Tour, the first for the way it ended, the second for the way it was run; each had its own function, which, for the first, was to unveil the name, and the second, to unveil that which was

\footnotetext{
"Train for health, and the disciplines learnt will do much to withstand debilitating disease. Train in teams, and the team spirit will help contribute towards national unity. Train to struggle for victory and to take defeat as a call to further effort, and the sporting spirit will help the nation build resolution and resistance [...."

On the same page (p. 118), is the photo of a mural devoted to badminton and the Thomas Cup with the caption:

"So important are sports considered for nation building and character building that a place was given to sports on the Panca Sila poster painted to honor the nineteenth anniversary of the birth of the philosophical basis of the State."
}

The publication's main byword, and consequently one of Indonesia's official slogans in 1964, was: "nation building and character building to consolidate independence" (p. 27). 


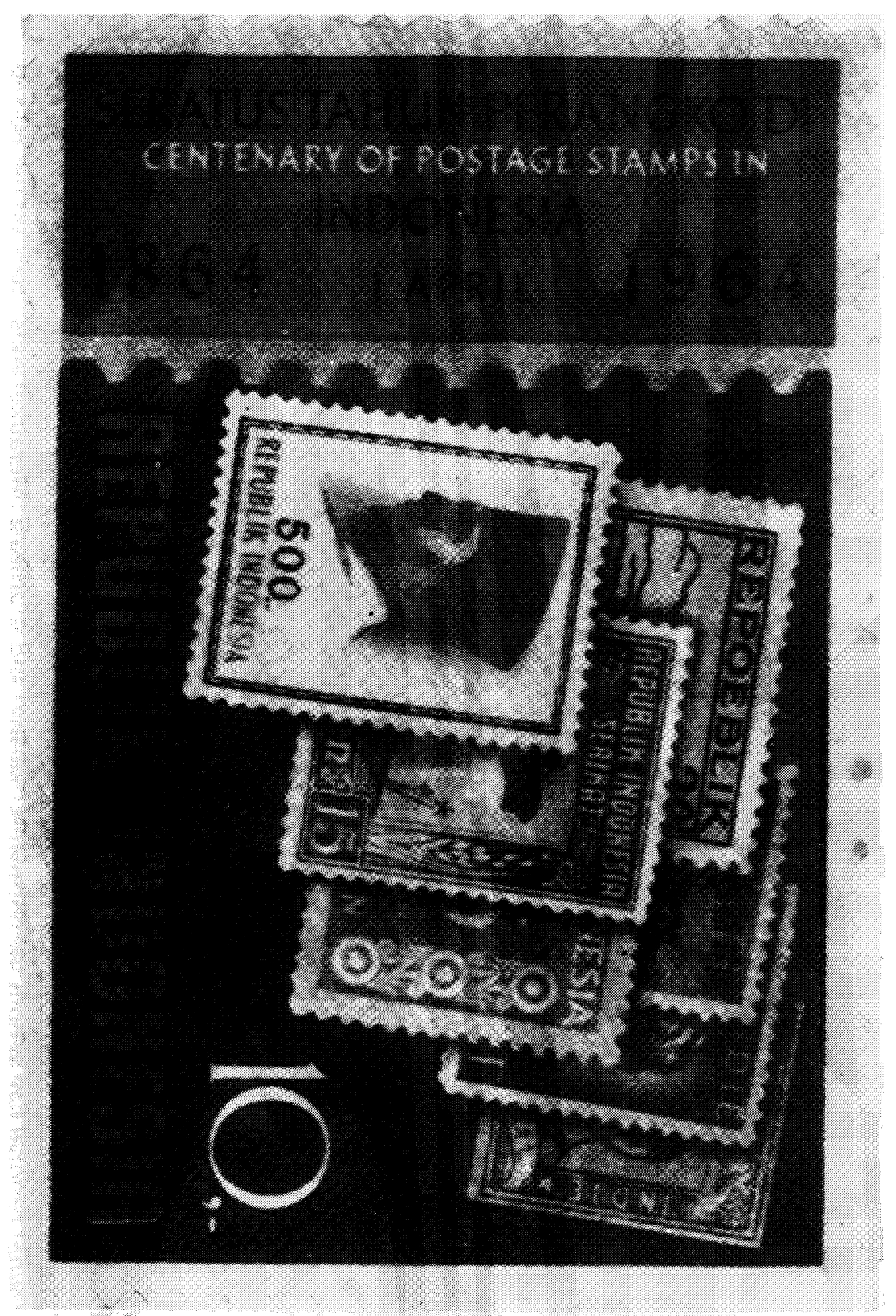

Plate I. Centenary of postage stamps in Indonesia, 1964 (maquette: Kartono).

A set of seven stamps evokes Indonesia's history, by means of the names of the successive States which named its territory: Ned. Indië; Japanese characters; Repoeblik Indonesia, in the Dutch spelling still in use during the "Physical Revolution"; Indonesia, as it was after the Renville agreements; Republik Indonesia Serikat, which came out of the Round-Table conference; and finally Republik Indonesia, the de-Netherlandization of the spelling of the primordial institution. The head of the Chief of State, symbol and upholder of the Constitution, on the last stamp, reinforces the identification of the stamp, on the occasion of this commemoration, with the State seal (which may also explain the frequent use of coats of arms as a motif: the transparent stamp gives way to the institution). The taxonomic role of the Constitution, as Kartono perceives it in his short history of the Indonesian postage stamp, as a witness to institutions, legitimates from within, as it were, the corpus used in this article: the stamps carrying the caption Republik Indonesia. 


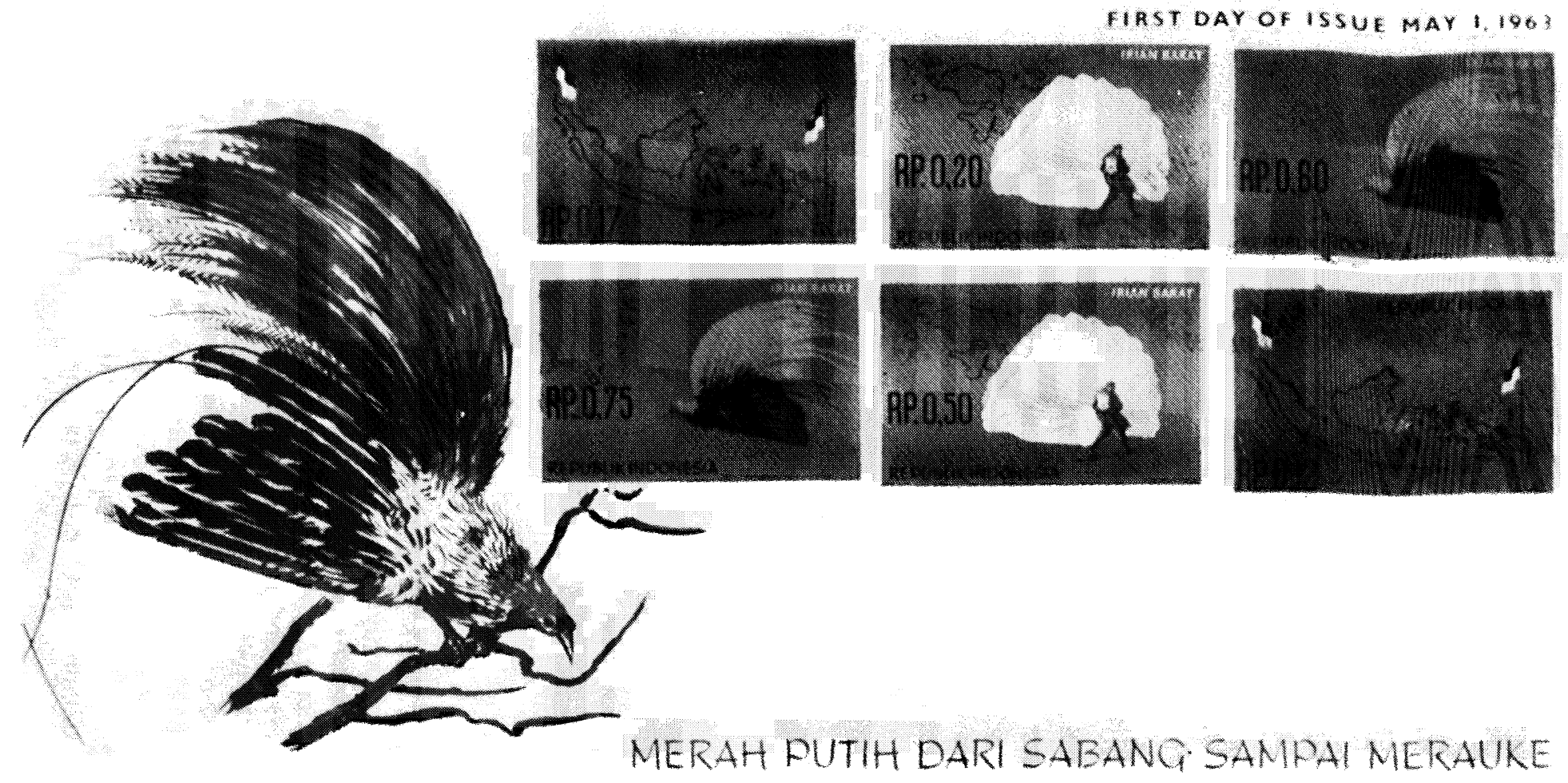

Plate II. First-day cover: on the occasion of Irian Barat's affiliation to the Indonesian Republic and the unification of Indonesia, from Sabang to Merauke, on May 1, 1963 (maquettes: Suroso).

The linguistic message on the envelope, "Merah Putih dari Sabang sampai Merauke," corresponds to the .12 and .17 rupiah stamps: the map of Indonesia with the red (merah) and white (putih) national flag at both the northwest (Sabang) and southeast (Merauke) ends. Irian, on the .60 and .75 rupiah stamps is designated by its map overprinted with a possibly totemic bird, the bird of paradise, the feathers of which were one of the forms of tribute most demanded from the peoples of Irian by the petty maritime rulers of the Moluccas; and its name (Cendrazasih) was taken by the newly established military command and by the University of the now Indonesian province, Irian Barat. History is actively present only on the .20 and .50 rupiah stamps, in the center of the system, thus both fiscally and ideologically joining the two ends: the Indonesian paratrooper coming to the region, giving the center back its periphery, a center therefore legitimated by its capacity for military intervention. 
named. Identified in this way, the trials were not only concomitant, they were first and foremost complementary.

The outcome, that is the attribution of the prize, and its attribution to Indonesia, was attested by the issue of the stamp (had Indonesia not won, there would have been no stamp: it is not the playing that counts here, it is the winning); and by the ribbons in Indonesia's national colors that decorated the Cup at the award ceremonies, and which the stamp reproduces, thus confirming the holder's name. On the 1958 stamp, which kicked off the set, an Indonesian flag flies in the background and a bilingual inscription DJUARA DUNIA BULUTANGKIS / BADMINTON WORLD CHAMPION underscores the proclamation.

Whether it be flags, sashes, or ribbons, the Indonesian national colors figure so rarely on stamps that their presence has a discriminatory value. Outside the context of the Thomas Cup, they appear only twice: once in 1963 on one of the stamps saluting Irian Barat's incorporation into Indonesia (see pl. II), and again in 1965, in the Panca Sila set, on the Kebangsaan stamp; both times they have a direct, figurative relation with the establishment of national identity through territorial integrity, the extension of Indonesian power to the whole territory of the former Dutch Indies.

The beribboned cup, object and sign of victory belonging to the winner alone, functions on its own level as an insignia and an attribute of Indonesian power.

Figure 4. The search for identity. Flag and national territory in their respective contexts (for the reproduction of the stamps mentioned, see pl. III).

The diagram is constructed around a double set of entries (the key-words: flag and national territory) while retaining significant secondary entries (as tools for covering the territory). Each stamp is designated by a rectangle indicating the object of the commemoration (these are all commemorative stamps) and the date of issue.

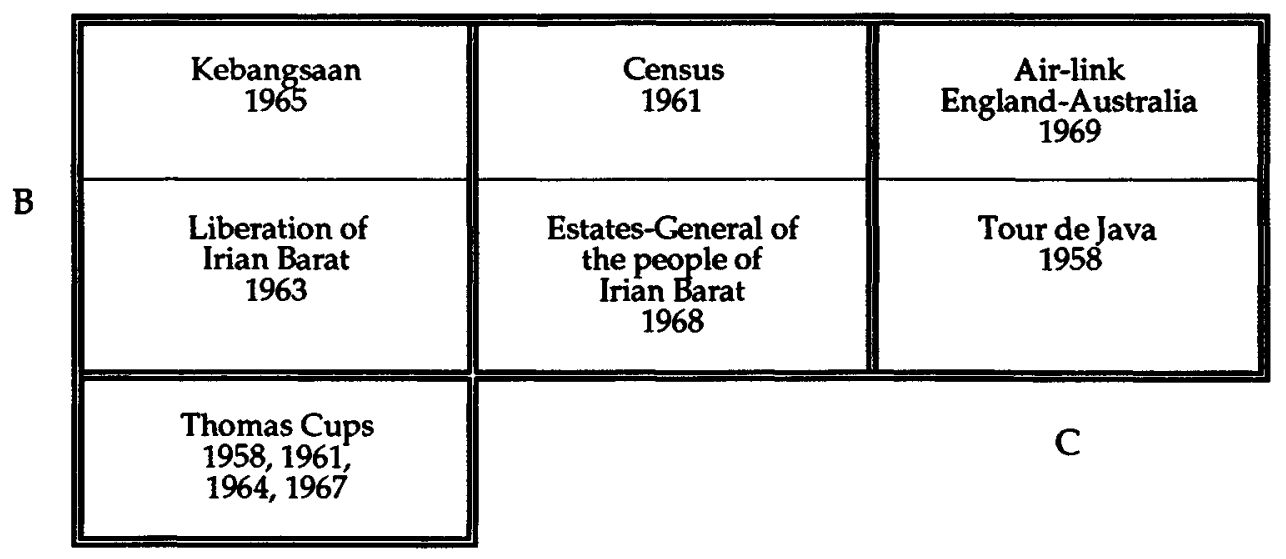

A

$\begin{array}{lll}\text { Key: } & \text { A Presence of Indonesian flag (ribbon, sash, etc.) } \\ \text { B } & \text { Map of Indonesia on part of all of the stamp } \\ \text { C Presence of a means of transportation }\end{array}$

NB: The stamp issued in Irian Barat in 1968, which figures here, was not circulated in the rest of Indonesia; it is therefore not included in the graphs of figure 1. Note the cluster constructed around the keyword Irian Barat and the possible semantic link between Kebangsaan and Population census, which by the name and the space occupied guarantee the force of numbers. It should also be noted that the limited field analyzed here is just one of the many intersections of the several groups indicated by figure 1 as a working hypothesis ("politics," "social work," "sports," "communication"). 

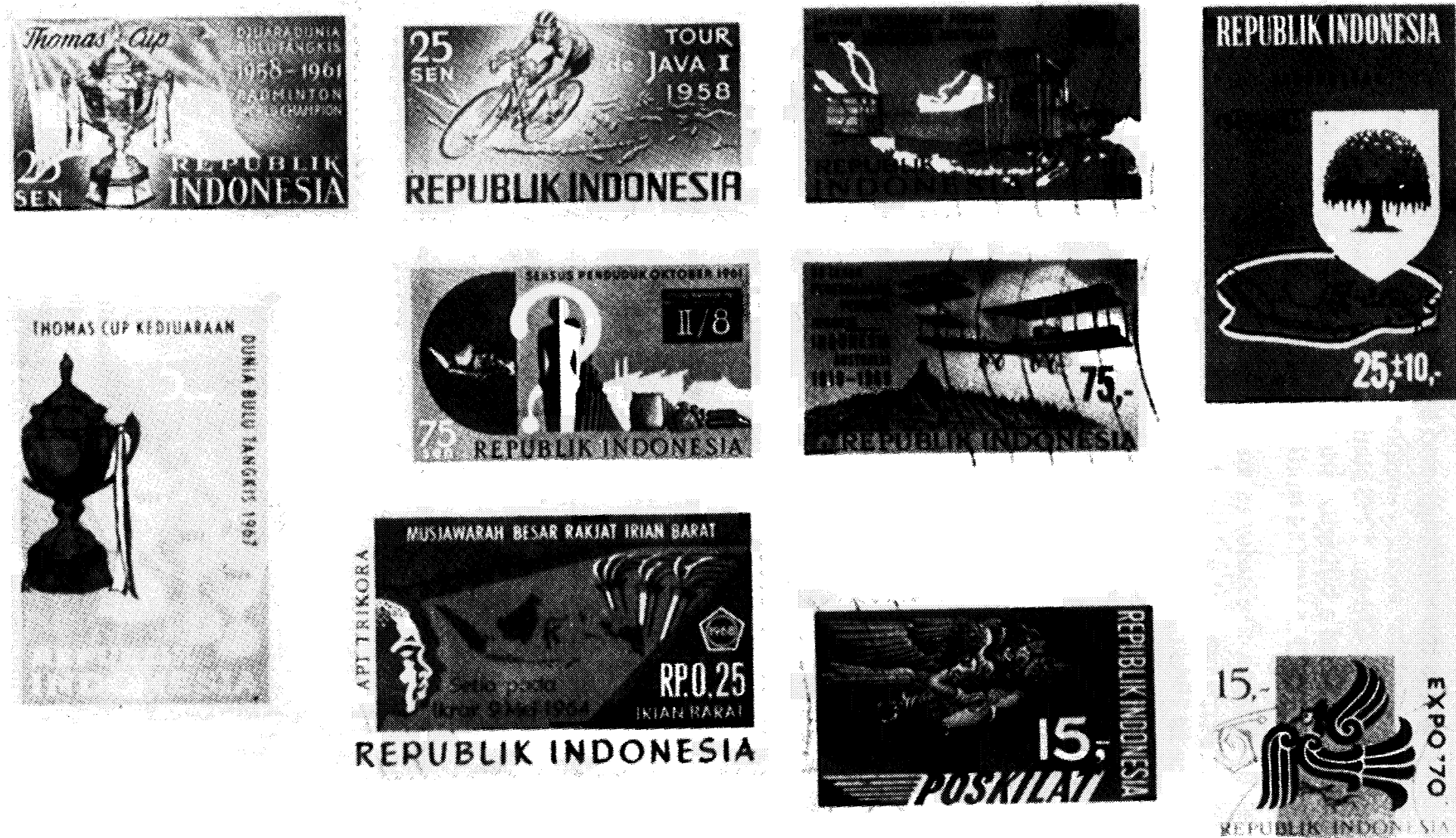

Plate III. Flag and national territory (cf. figs 4 and 5)

For technical reasons, we have also reproduced the stamps which repeat or in some way carry on the biplane/Borobudur theme (cf. 5.3.2), by using, as a symbol for Indonesia, Garuda, Vishnu's eagle, which stands for both speed (Postkilat: express; kilat: lightning) and development (the Indonesian pavilion at the Osaka exposition). Garuda is also the name of Indonesia's national air transport company and a basic component of the State arms, as they figure, for instance, on the stamp issued August 17, 1950 (cf. 4.1.1). 

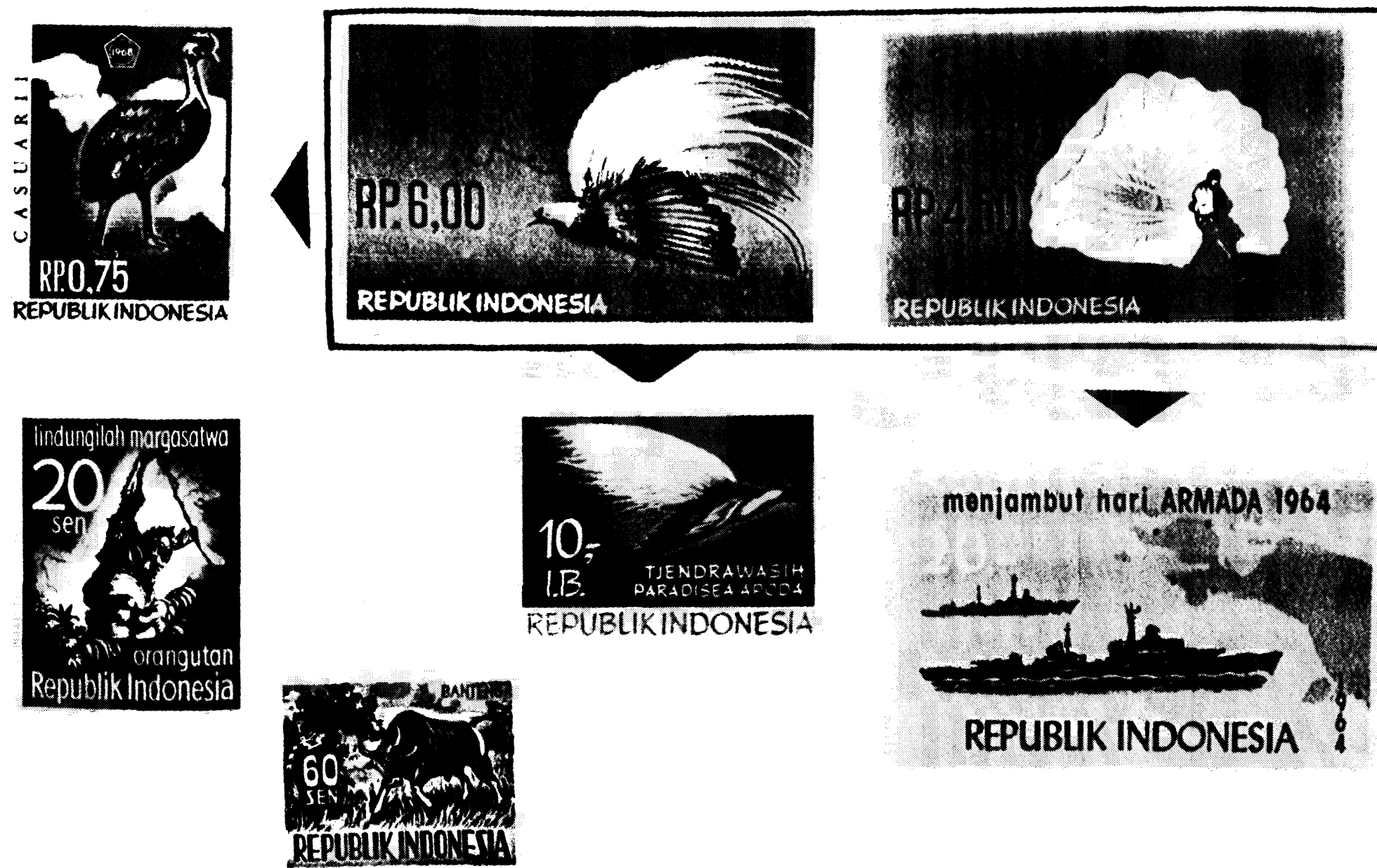

Plate IV. Bird and Paratrooper in the 1963 "Irian" set.

Plate III sought out the isolated elements-map of Indonesia, national flag-that had been grouped on one of the stamps shown on plate II. Here we take a closer look at the field and the formal components of the two other stamps in the set. If the paratrooper gives rise to the 1964 stamp that associates the navy (Hari Armada: Fleet Day) with him, in the struggle to recover Irian, the territory/ "totemic" bird system featured on the last stamp fits into a circuit of symbolization-desymbolization-announced here first of all by two stamps that appeared only on Irian: the one isolates the bird; the other takes over the map as the geographic and non-historical location of another bird (the cassowary: the complete set presents, against a background map, four different plants and four animals); the animals pictured against their background map bring us back to a set, Lindungilah Margasatwa (Protect Wildlife), issued in 1958 (cf. fig 10), which, if the geographic indication is removed, brings us back to the 1956 Khewan (Wild animal) set, into which the above-mentioned isolated bird of paradise, also fits. From the Khewan set we have chosen the banteng to illustrate the desymbolization of an animal highly charged with national symbolism (shown holding the Indonesian flag on the first stamp of Repoeblik Indonesia in 1945; the head of the banteng on Indonesia's coat of arms, and thereby on the stamps patterned on it, indicates the Sila Kedaulatan Rakyat (sovereignty of the people). 
The 1963 and 1965 configurations ${ }^{5}$ combine the colors of the map of Indonesia with the name of the territory it names: flags raised at Sabang and Merauke in 1963, a sash delineating the space already indicated, in 1958, with respect to the Tour de Java, a trial run that turns into a perpetual-motion circuit broken only by human time, the course and the wheel, a course which imposes upon the image another actor, the cyclist, the worker, the man (fig.4).

What counts, then, is not a winner or a cup, it is the race and those who run it, who identify it, giving its land in the name that the Cup has pronounced.

5.3 Is the 1969 stamp, with its map of Indonesia overprinted with the biplane in which Rose and Smith made their 1919 flight from England to Australia, a double of the Tour de Java? But, for these aviators, the territory beneath them was the Dutch East Indies, and it was their eyes-and theirs alone-that measured its spaces, and it was their flight that went down in history, and their story that figures on the stamp.

5.3.1 The inscription 50 TAHUN PENERBANGAN PERTAMA INGGRIS INDONESIA AUSTRALIA 1919-1969 emphasizes INDONESIA by setting the word in a larger type size than the rest, thereby creating a redundancy with the background map (see pl. III). But Indonesia's role in the event was limited to providing a fleeting stopover (like colonization, the English plane stopped only to refuel), a result not of its history but of its geographical location; the landfall is purely an object, and doubly so, since it is Indonesia only for the author of the stamp and his contemporaries. The stamp issues an invitation to a retrospective celebration; this is the Visitation, the allegory of Indonesia touched by the grace of Aviation, the intoxication of a desire and the revelation of a promise.

While the Tour de Java circumscribed a dwelling place, the England-Australia flight indicated a passage, a channel. Antithesis: the bicycle was a point on the circuit that was Indonesia, Indonesia was a point on the route of the plane; from the discovery of the national space to the discovery of the wide world, if the traveler was from here. The Jatiluhur relay station, too, was a point in space, inaugurated the same day as the issue of its commemorative stamp, on September 29, 1969: President Suharto opened the satellite communications station (cf. fig. 5) by calling Indonesia's ambassadors in Washington, London, and TokyoAmerica, Europe, and Asia-the entire world, but not just any place there, ${ }^{6}$ this was the triangulation of financial capitals for which Indonesia represented a well-placed investment. Representing a transition, perhaps, from politics to economics, the PELITA set (PELITA means lamp, but is also the acronym for Pembangunan Lima Tahun - the five-year development plan just launched), issued on August 17, 1969, defines the coordinates.

5.3.2 But two stamps are devoted to the 50th anniversary of the England-Australia flight. On the second, the biplane is passing over Borobudur, which is pictured as being identical with Indonesia, an identification already established (see 5.1) on the 1951 stamps announcing the first Asian Games, if not an arbitrary choice, at least a product of chance. Borobudur,

\footnotetext{
5 In the sense of a montage of figures in one technically and culturally defined place, in this case the stamp (cf. Pierre Francastel, La figure et le lieu [Paris, 1967], p. 347).

6 Indonesia Magazine, a show-case semi-official bilingual publication aimed at a foreign audience, devoted pages 2 and 3 to pictures of the station's parabolic antenna and the President on the telephone; the second issue (1970) showed a picture of the antenna with the following caption: Antene stasiun satelit bumi di Jatiluhur. Proyek komunikasi yang dapat menghubungkan Indonesia dengan Washington, London dan Tokyo melalui satelit Intelstat III telah diresmikan pemakaiannya oleh Presiden Suharto pada 29 September tahun yang lalu (p. 28).
} 
Figure 5. Space, image and relational function. Confrontation of stamps signalling mobility and immobility. The prestige of power and the power of prestige (the dates are issue dates).

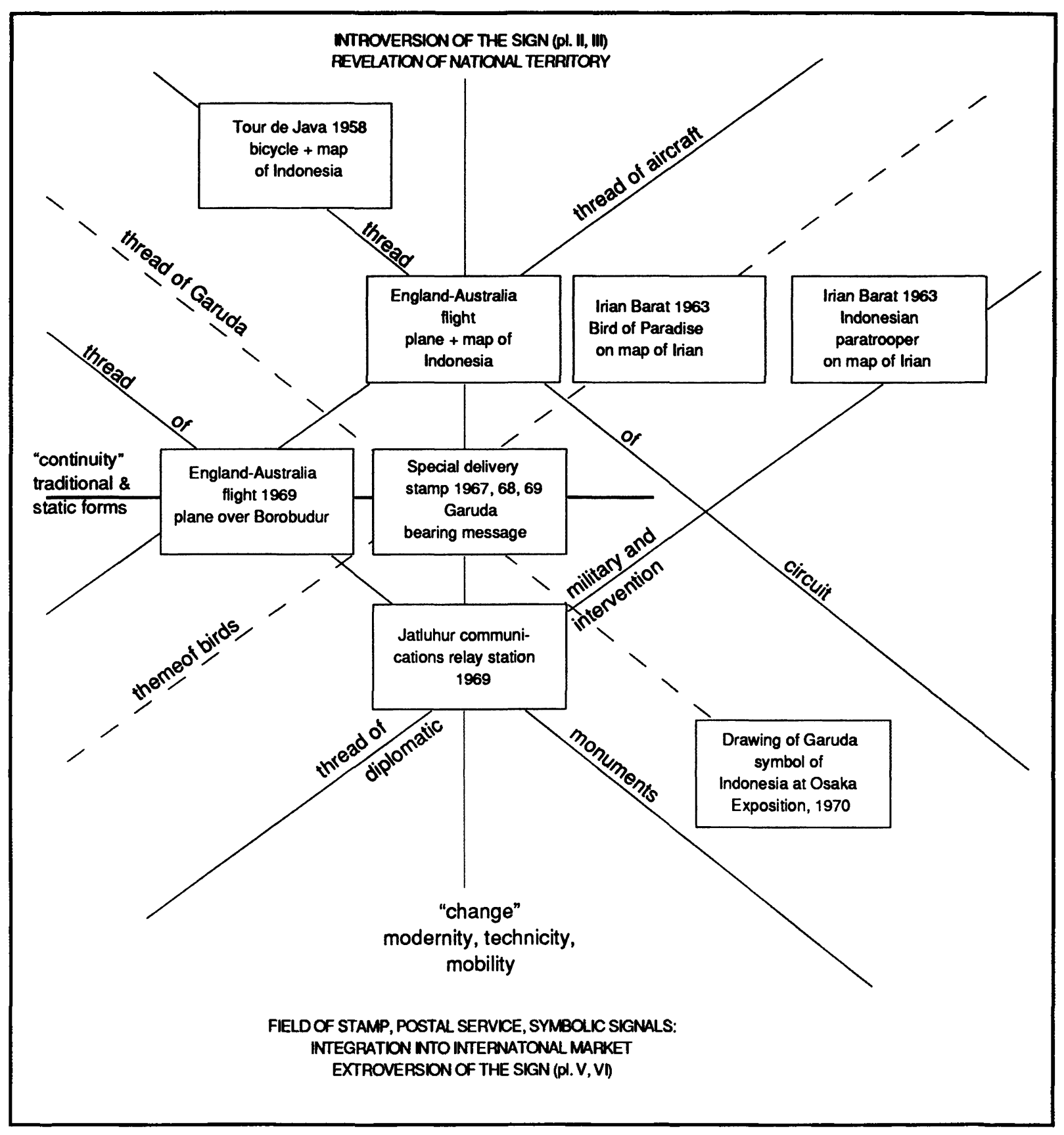




\section{Jacques Leclerc}

Figure 6. National, political, and technical identity, after the stamp "50th Anniversary of the England-Australia air-link," showing the biplane flying over Borobudur (maquette:

Suwarsono, 1969; see pl. III)

"Enclosed in being, one must always issue forth. Hardly has one come forth from being, than it is time to retum. And so, within being, all is a circuit, all is circuitous, full circle, locution, circumlocution, stays, delays; all is a refrain of couplets without end." (Gaston Bachelard, La Poétique de l'espace [Paris, 1957], p. 193).

INSIDE

historical time

circle of the political space

dynastic culture

the mountain

\section{OUTSIDE}

dilution of the territory

periphery

trajectory

the cloud

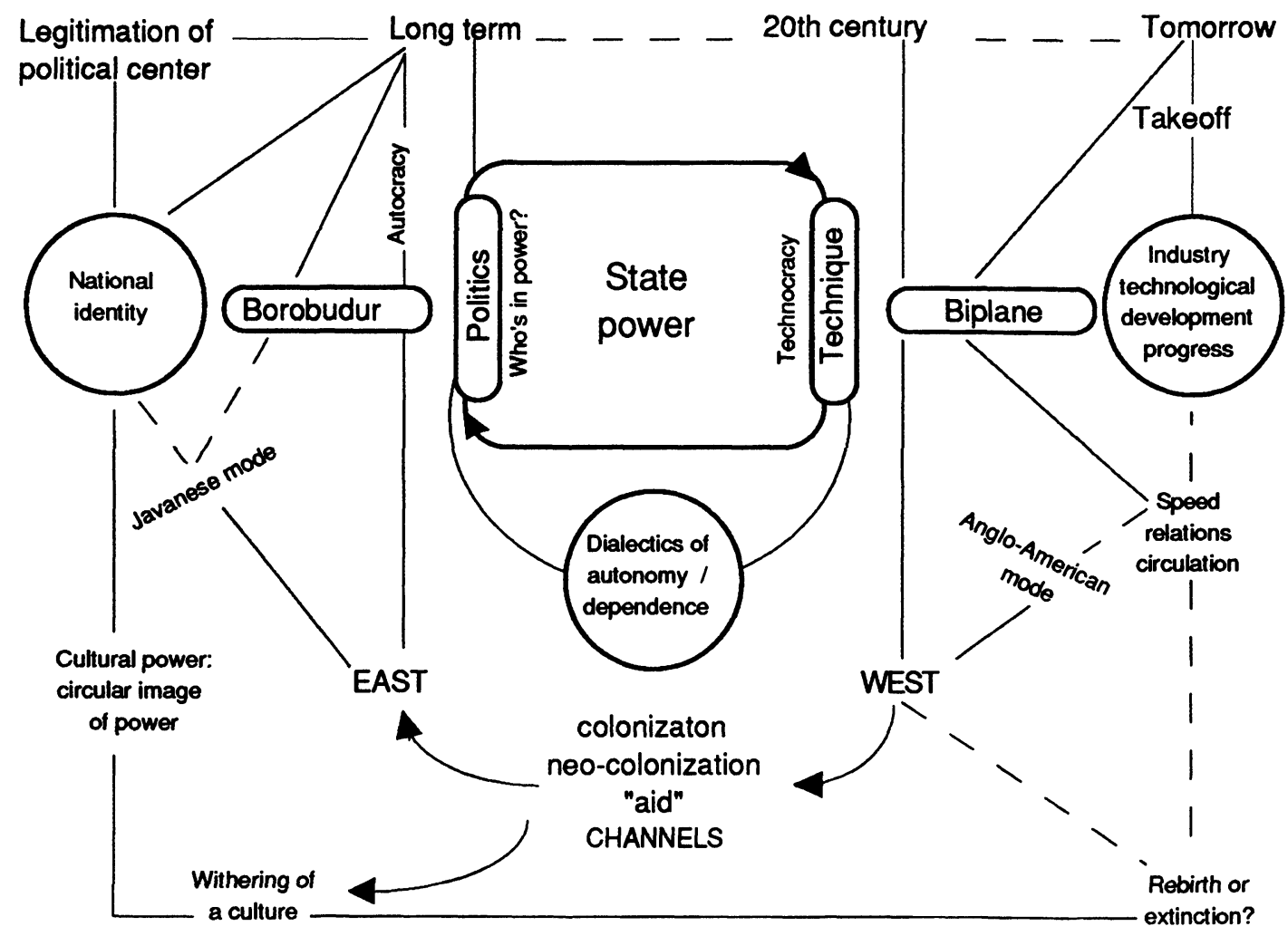


which identifies Indonesia by its central monument ${ }^{7}$ and its relationships with ancestors and dynasty gods, opposes the verticality of one tradition, singled out because of its architectural visibility, with the "biplane," sign of the relation with others in the horizontality of contemporary life. But also the vertical plane in which is inscribed the curve of the takeoff, the line of development traced by its own product, the "figure of an arrow" working, as Bachelard says, "in harmony with the imagination of dynamicity," ${ }^{8}$ put into accord with the finite ground which the shores of memory mark off with the surveyor's measure.

Is there no escaping Borobudur?

The rock rooted to the ground, clinging to the earth like a child to the breast, like a breast to the mother, the sacred weight of rural sedentary habits, a concentric blueprint organizing and closing forever the space and its history, the hieroglyph of power. To the Westerner who has exhumed it from its millenial ruins, Borobudur is a mirror into which the Occident looks and recognizes its own Orient, seizes its soaring reflection, the desirable object of a dream-Occident, mechanical and fluid: a transfer of Othernesses.

But what was the circuit constructed by this external gaze? Inner space, ceremony, and ritual, as an alienated spectacle, was soon no more than a commodity on which the plane unleashed its antique dealers. ${ }^{10}$ Singled out in this way, for the unique Other, as venal

\footnotetext{
7 The identification of Borobudur with Indonesia, which calls up the Java/Indonesia relation on the 1958 Tour de Java stamp, is not self-evident: it implies choosing among the pusaka, the inheritance in which law is grounded, the choice that asserts or confirms (this is not the place to discuss the matter) the preeminence of the Javanese states over the other historical states of the Archipelago as builders of its unity, and singles out the HinduBuddhist culture as being most representative of the country (whence certain centrifugal reactions, in activist Muslim circles, against a certain political élite's "modjopaitisme," which they denounce as an archaic relic of the dominating bureaucracy of these former states (cf. Kahar Muzakar's article cited by H. Feith and L. Castles in Indonesian Political Thinking, 1945-1965 [Ithaca, 1970], p. 330). None of the stamps issued between 1945 and 1950 , during the "Physical Revolution," a period of intense national demands, carries a picture of Borobudur, the symbolism of which appears to be more a function of the interest on the part of representatives of Western culture operating in Indonesia, that is, introducing de facto international recognition of the country. Curiously enough, the exhibition, "Indonesian Art," organized by the Amsterdam Museum of the Tropics, then the Museum of the Indies, at the Chicago Institute of Art in the spring of 1949, presents, out of a catalogue of 686 items, 218 objects from Sumatra-Nias and only 213 from Java-Bali (and 73 from Irian Barat, which no one at the time dreamed of excluding from Indonesia: the police had just carried out their second operation, and the Netherlands were no doubt still on the defensive), while nearly all later catalogues and art books concentrate on Java-Bali (we know that the Round-Table agreements, signed in the last days of 1949, reduced the Republic of Indonesia to precisely the region of Borobudur, in other words, roughly the eastern half of Java and the area west of Sumatra); not only works entitled "Ancient Indonesian Art" - those by Bernet Kempers (Amsterdam, 1959) or the one by J. Fontein, R. Soekmono, S. Suleiman (New York, 1971), which carries the subtitle "of the Central and Eastern Javanese Periods" - but also those taking in the whole formal and temporal scope of Indonesian art-F. Wagner, L'Art d'un archipel (Paris, 1961), 40 photos for Java-Bali, 23 for the rest of the archipelago; C. Holt, Art in Indonesia (Ithaca, 1967), out of 150 illustrations, only 25 outside Java-Bali; only the recent work by Tibor Bodrogi, perhaps both because it was commissioned by UNESCO and because it was written by a specialist on Oceania, devotes only 77, out of 188, illustrations to Java-Bali ( $L$ ' Art de l'Indonésie, [Budapest, 1972]).

8 La Poétique de l'espace (Paris, 1957), p. 212.

9 The signal of the arrow appeared twice on stamps in 1970, "The Year of Productivity," and figures again in the shape of upward curving half-circles on one stamp in the PEITA series already mentioned; it also informs the "obelisk" signs (cf. pl. VII); the "thread of the airplane" mentioned in figure 5, for which the arrow is one possible metaphor, occurs frequently, especially in 1958 and 1967 (Aviation Days); cf. fig. 1, graph E/e and its explanation.

10 "Visit the Orient Year" (1961 set, including a view of Borobudur).
} 
Figure 7. National holidays and commemorative issues (cf. 4.1.1)

Four commemorations are considered here, the most important being that of the Proclamation of Indeendence, August 17, then Hari Pahlawan, November 10 (1961 and 1962: Pahlawan Kemerdekaan stamps; 1963: the GANEFO set; 1966: the dead of October 1, 1965), October 5, "Army Day," which in 1961 and 1962 is marked by stamps in the Pahlawan Kemerdekaan set, and in 1964 by a set in honor of the war fleet (cf. pl. IV); May 20, the anniversary of the foundation of the Budi Utomo movement which does not appear until 1962, for the presentation of the National Monument. The use of stamps for commemoration is remarkably regular from 1959 to 1967, which roughly corresponds to the period of Guided Democracy.

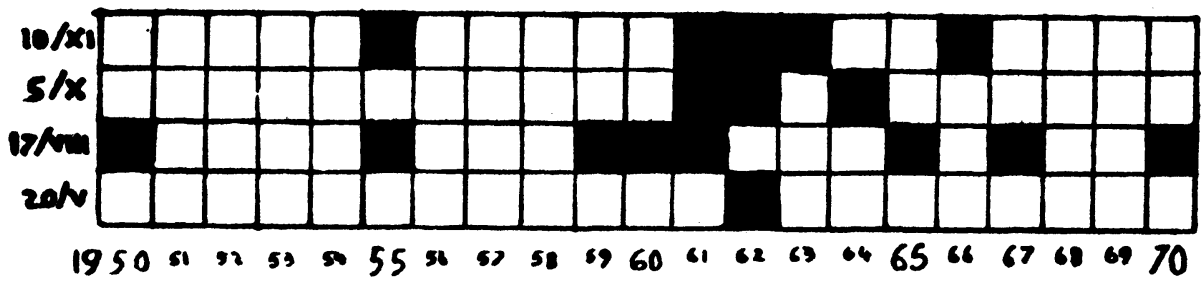

curiosity, long inaudible at this price, Borobudur died a shoddy death, unless it died simply from being reborn, from returning, with no power, to a land with no means. ${ }^{11}$

5.3.3 From piecing together the terms of the dilemma, no more could be learned about relationships than from such titles as Tradition and Modernity or Continuity and Change, AngloAmerican sociological treatises on transition. Contradiction or filiation, confrontation or coexistence, domination or cooperation, internal or external factors, all combinations are (apparently) allowed.

Correlations there have been between within and without, center and fringe, point and expanse, planet and satellite, immobility and movement, stagnation and development, the lasting and the passing, continuity and break, but for all that, the image has not indicated any choice among these impassive terms of a debate which, already in the 1930s, divided the Pudjangga Baru contributors over the question of Indonesian culture: a correlation founded on a figurative reduction of history to objects of worship, monument-moments in a civilization that brought them forth, convergences of both a host of types of knowledge and of techniques, crystallization of the meticulous work of thousands of engineers and laborers, would-be instruments of domination and prestige of the caste or class that lays hold of them for its own glory when it incorporates this into the history of a flight, a flight above history, simply dissimulating behind the unformulated invasive thrust of desire the only question, the twofold question: who is at the controls, and where is he heading?

5.4 The 1962 Asian Games precipitated the largest issue of stamps of the 1950s and 1960s, in terms of the variety of images diffused, twenty-one in all: the run up, publicity drives, one of the public works that accompany, underwrite, and qualify the organization of Olympic encounters, some of which are featured on the stamps themselves.

5.4.1 In a certain sense, the Indonesian stamp missed out on Bandung. The greatest international event in the 20th century history of the Archipelago produced, in 1955, four values for one small stamp, whose discretion, moreover, corresponded with that of the other

11 The "Save Borobudur Monument" set (1968) in connection with the restoration campaign launched by UNESCO. The linguistic message on this set of stamps is in English only. 
stamps issued at the time. In 1962, the Games, as an international manifestation on the scale of the Asian Continent, demanded-this was a new international recognition of Indonesia, where they were to be held-that, in return, Indonesia confirm its legitimacy. This was not a mere Badminton World Championship, hosted by Jakarta, as the previous year; this was a gigantic system of qualification, of which the selection of Indonesia as host was only the first stage. The Games, a civic celebration, a placement examination, were continued in the very welcome extended: stamps were one of the most flexible and colorful instruments. And in fact the progress of the Games through qualification and elimination, made them symbolically more significant than the Bandung Conference, for the functional reality of the Games and their organization, like that of all ceremonies, is purely symbolic.

As what was important in the philatelic celebration of the Badminton Championships was Indonesia's victory; what was important in 1962 was Indonesia's qualifying as the very locus of the championship of championships: the nation proved itself to itself by proving itself, by carrying out its function of host, to all the other nations. On every level the championship, a tournament system, a system of binary oppositions finally established Indonesia as a discrete whole that could be seen and identified, taking an active and willing hand in its own identification and, in so doing, fashioning its own identity.

5.4.2 That is a very different qualification from the also internationally acknowledged one illustrated by Borobudur: the history that produced Borobudur also gave the archer his place of honor among the first stamps introducing the Games (see above 5.1), but this piece of history needs to be recaptured; of this recapture, the Games were a sign grounded in experience. As an international competition, they were an abridged version of the nation's history, a metaphor of survival and the struggle for life, the inexorable parade of challenges continuously to be accepted in order first to assert and then to fortify the nation's attitude toward challenge, as the principle of sovereignty, the act that names Indonesia the subject of its history, a history of effort, presence, and communication.

5.4.3 But exactly what kind of communication and, in the end, what kind of sovereignty? It was not Indonesia that did the choosing, it was the International Olympic Committee that decided the teams Indonesia was to host. Were Indonesia to refuse to receive the bad sports, Israel or Taiwan, the IOC would immediately withdraw its accreditation. Whence came the defiant GANEFO (Games of the New Emerging Forces): Indonesia decreed who and when. Who? The criterion was not gymnastic activity but political solidarity, without which the sports were mere amusement and Bandung a dead letter: bring together birds of a feather, as it were, so that the competition might be truly peaceful and the challenge of the Games a new type of communication. When? The 10th of November "Heroes' Day" (see explanation pl. VIII), celebrating the pioneers of Independence. Because the games were a fight, there was no question of fighting indiscriminately friends and enemies; and if fighting was a game, then let friends play together to fight the enemy, by isolating him. The November 10, 1963 issue of a set of eight stamps devoted to the GANEFO, seems modest enough: the Asian Games had given rise to 24. But it was no doubt of no use once more to describe the various sports on the program, for that was not the meaning of the event: the parading of the GANEFO banners, a show of group exercises (no struggle but the discipline of one movement, performed in unison), and the symbols: the official badge and the motto launched by Sukarno, Ever onward, no retreat, and the Olympic flame, which is not the exclusive property of the IOC, which takes its place beside the flame of the National Monument (pl. VI), axis and growth of Indonesia-civic education covers physical education, rejecting the purely technical and technocratic conception of the heirs of English leisure. 

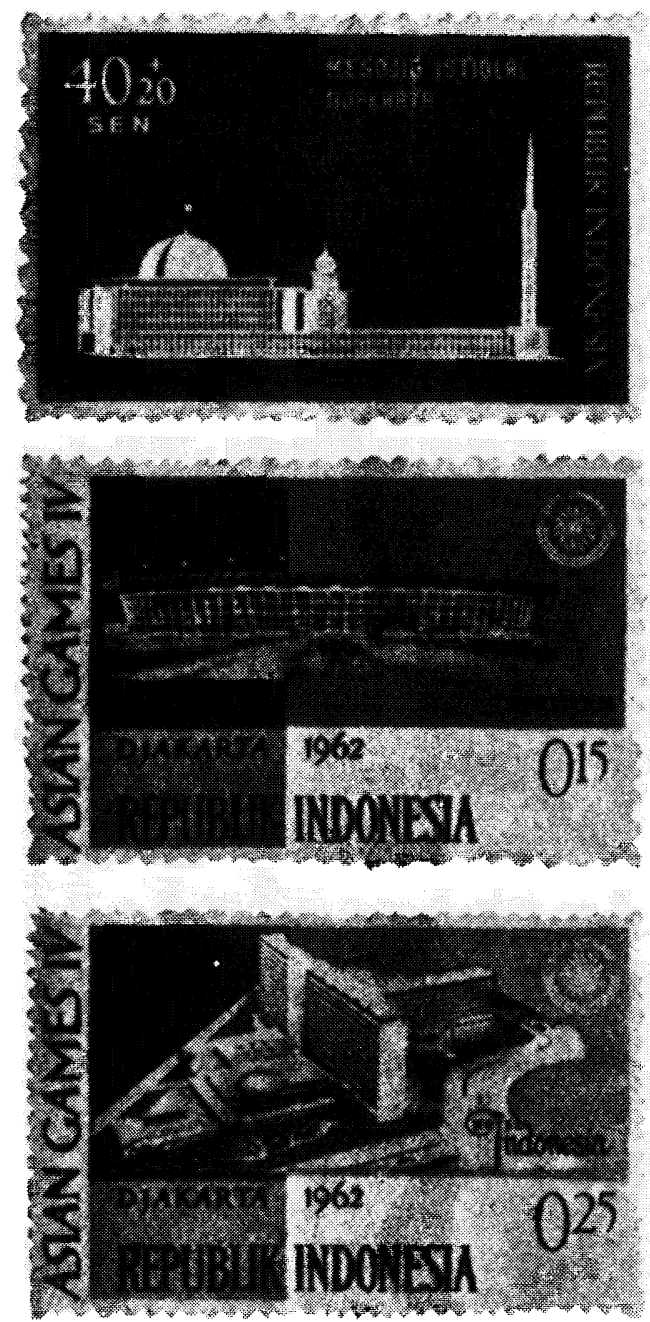
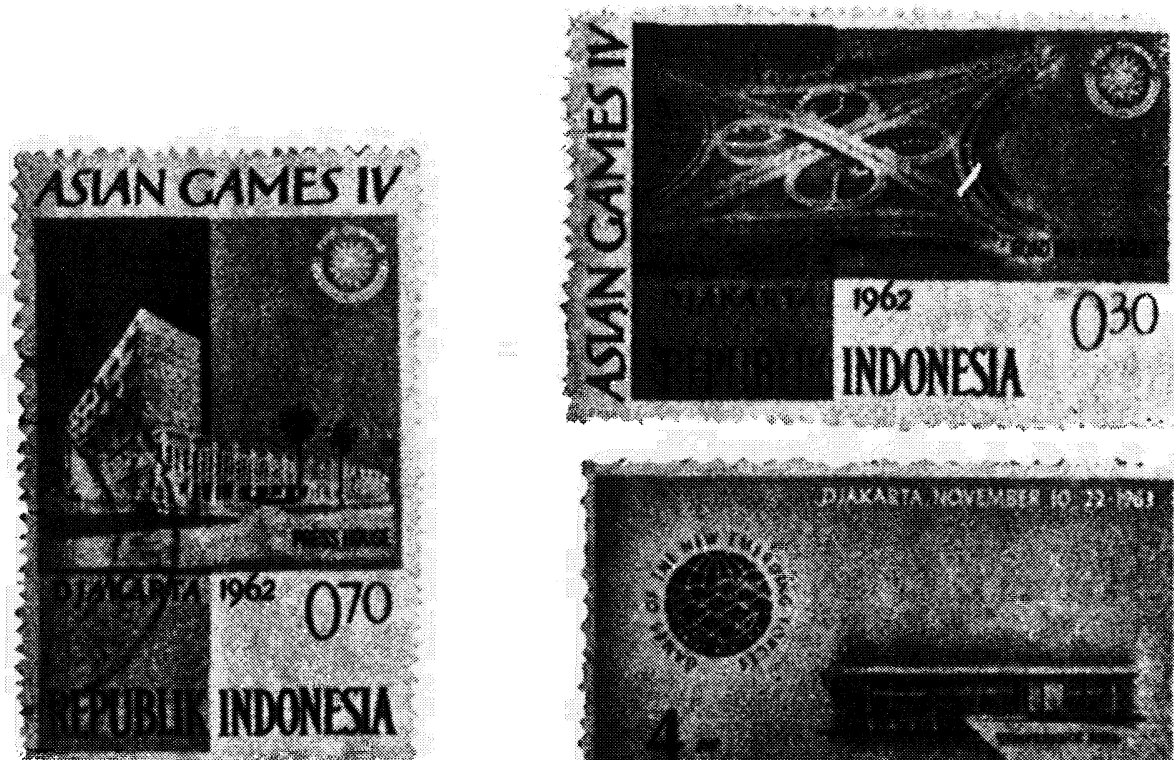

$\stackrel{\infty}{\infty}$

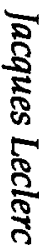
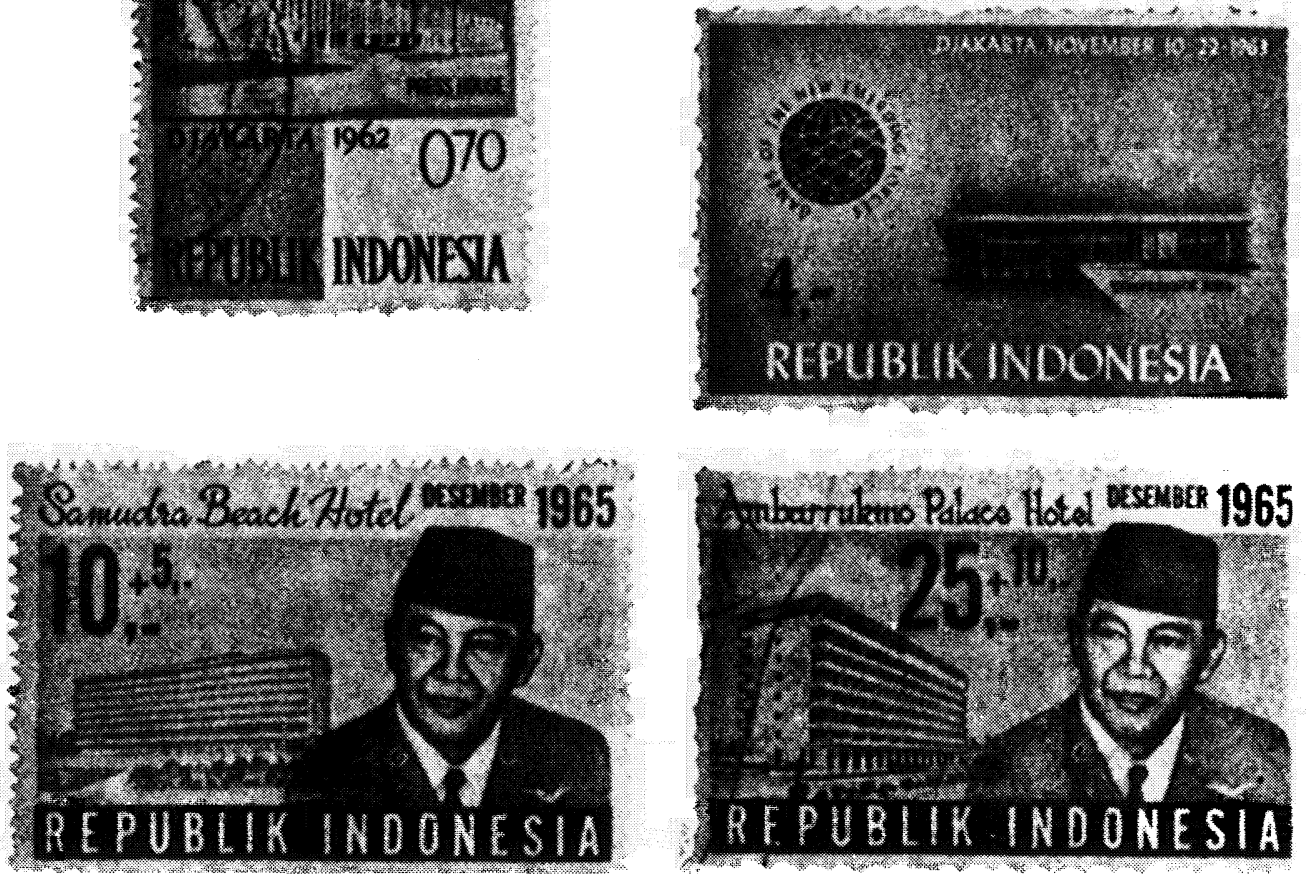

Plate V. Recipient, welcome, gathering: games and urbanism; importance of the hotel, the official guest room of a State that can choose its friends and issue invitations-sign of sovereignty (cf. 5.1, 5.4, 6). 

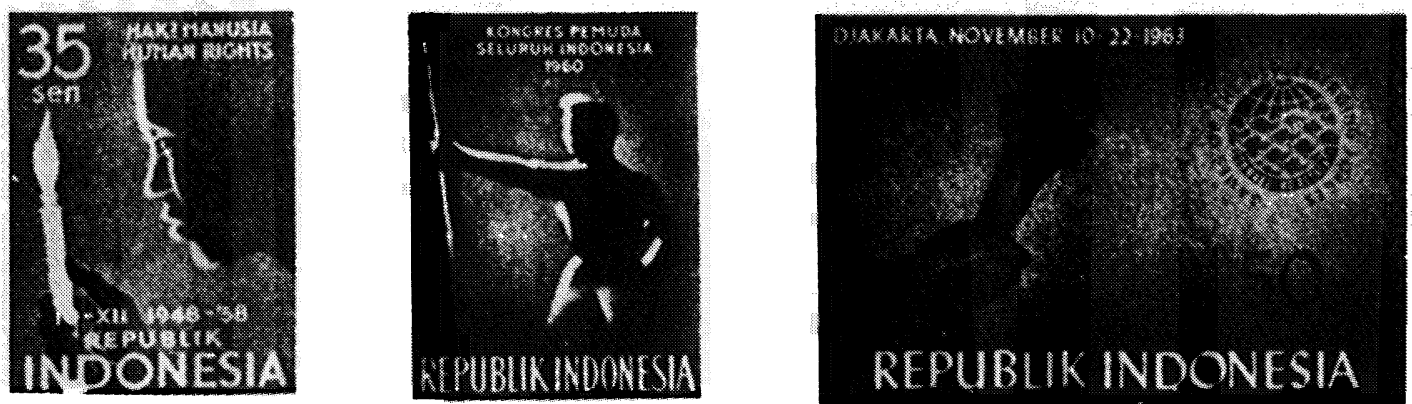

\section{ASUAN CAMES IV}
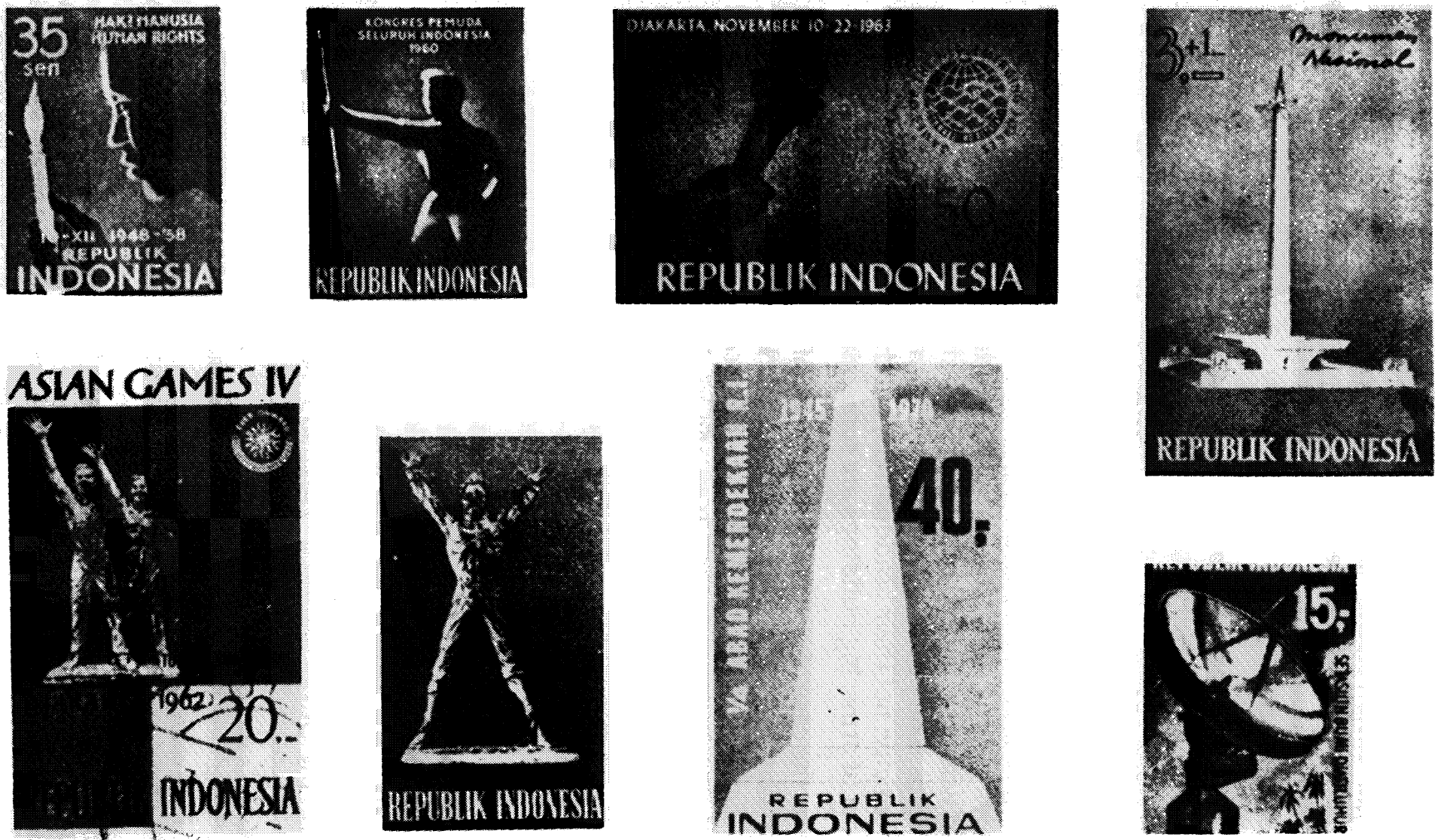

Plate VI. The beacon and the center: the National Monument, obelisk and flame, like a figure of paku alam, paku buana ("nail of the universe," royal titles in Central Java); the open arms, sign of freedom and welcome (selamat datang), which parallels the obelisk; the Jatiluhur antenna, a kind of synthesis of the cloverleaf as a traffic regulator, of the stadium as a parabolic form, of the minaret and the obelisk (pointing skyward), open like the arms of the statue, oversignified by its technological prestige (but eccentric - we are $100 \mathrm{~km}$ from Jakarta -and having the inverse function, cf. 5.3.1). 
When, in 1968, the Indonesian postal service first mentioned the Olympic Games, then being held far from Indonesia in Mexico, it was done by the graphic decomposition of a movement (weight lifting, a basketball player shooting a basket, a sail boat leaving the starting line), the space of a movement encompassed in the space of a stamp. The world was at last called by its name, but it was a mere student drawing.

\section{Inscribing the Center (see pl. V and VI)}

6.1 The building, organization chart/maquette of the city/society, by its manifestly visible physical solidity, settles down complete with privilege in the desire of the power for idealization/ monumentalization, political stability and historical memory, and the permanence of its identity/identification.

6.2 Jakarta's public works projects, samples of which were featured mainly in the sets issued for the Asian Games and GANEFO: cloverleaf, stadium, conference hall, press center, hotel, all organize a passageway, a space for receiving, gathering, informing, marked out by statues, obelisks, spouting fountains. The outline of the center.

\subsection{Public buildings, which does not mean administration buildings.}

As far as the administration is concerned, little more had appeared on stamps, from 1953, than the post's own issuing center, the Bandung headquarters of Post and Telecommunications; and what was first featured of the Bank of Indonesia's headquarters in Jakarta, in 1963, were the fountains. The public authorities and administrations are designated by the mark of their authenticity: not their headquarters, but their official seals. The face of the administration is its coat of arms; big buildings are something else again.

6.4 Take, for instance, the case of hotels. The maquette of the Hotel Indonesia (Jakarta) appeared in the "Asian Games" set; in 1965, a set entitled "Hotels" featured two maquettes: Samudra Beach Hotel (Pelabuhan Ratu) and Ambarrukmo Palace Hotel (Yogyakarta); half the stamp is occupied by the head of Sukarno. In 1969, the set devoted to "Tourism," issued yearly since 1967, shows various features of Bali; in this case, half of each stamp is taken up by a map of the island on the southeast point of which is located its emblem, a copy of that of the Hotel Indonesia, ${ }^{12}$ the international hotel that had just been completed. The configuration, as well as the iconic context of each of these sets-1962, 1965, 1969-obliterates any semantic convergence there may have been, but traces an itinerary of meaning.

The only link, in the list of hotels published on stamps, between the Samudra Beach Hotel, on the southwest coast of Java, practically equidistant from Jakarta and Bandung-the capital and its twin-and the Ambarrukmo Hotel in Yogyakarta-capital of the anti-Dutch resistance movement-is the existence of a legend, a myth relating the founding and the transmission of power, the legend of the Queen of the South (Roro Kidul), to whom the beach belongs (Pelabuhan Ratu, the Queen's port), the regular renewal of the alliance ${ }^{13}$ which

\footnotetext{
12 This emblem was featured on a stamp issued in 1972 for the tenth anniversary of the Hotel Indonesia. There is a semantic identity between the Balinese hotel shown in 1969 and the Jakarta hotel as perceived in 1972.

13 On the ritual of alliance at the court of Pakubuwono, another of Mataram's heirs, in Surakarta, see K.G.P.H. Hadiwidjojo, "Danse sacrée à Surakarta," Archipel, no 3, p. 117. The 1965 stamps fall outside the myth: two are greenish in color, whereas green, the color of the sea, is unfavorable for alliances. Or, in view of the issue date figuring in big numbers on the stamp, December 1965, might it not also be a way of asserting that, however dramatic the events rocking the country may be, Sukarno is still the founder and architect of the nation's stability. Or even to remind Sultan Hamengkubuwono of Yogyakarta, Sukarno's most constant and serious political enemy, that then, as always, the appanage of Yogyakarta is part of the Indonesian Republic and not the contrary.
} 

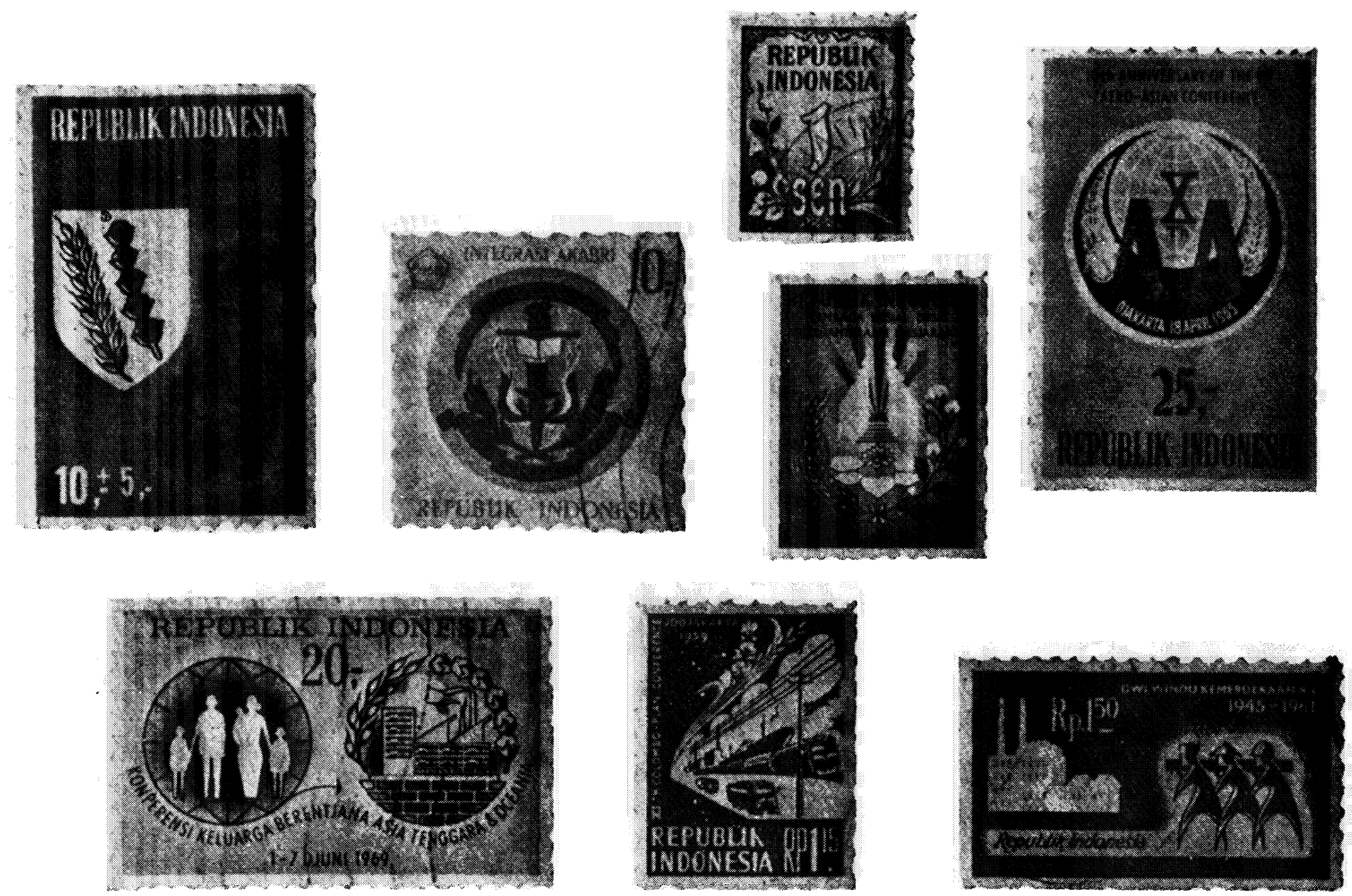

Plate VII. Blazoning and un-blazoning: padi-kapas and building (cf. 4.2)

The trend toward the use of coats of arms appears as a figurative practice, the instituted or, better, institutional vocation of which is the assertion and recognition of identity (cf. "Signes de reconnaissance," Pierre Francastel's preface to the catalogue of the exhibit Emblèmes, totems, blasons (Musée Guimet, Paris, 1964) and Georges Mounin's criticism in "Le Blason," Introduction à la Sémiologie (Paris, 1970). The stamp reveals this vocation either by repeating an external, already established coat of arms (cf. pl. I) or by organizing itself as an insignia by regrouping elements that are identifiable as possible armorial features. The padi-kapas combination seems to be one of the first constant, isolable discrete units of a nascent heraldic code. But context can also disfigure the emblem and give it a new meaning. Here another configuration, dwiwindu kemerdekaan (cf. 4.1.3) has been added to the examples using padi-kanns 


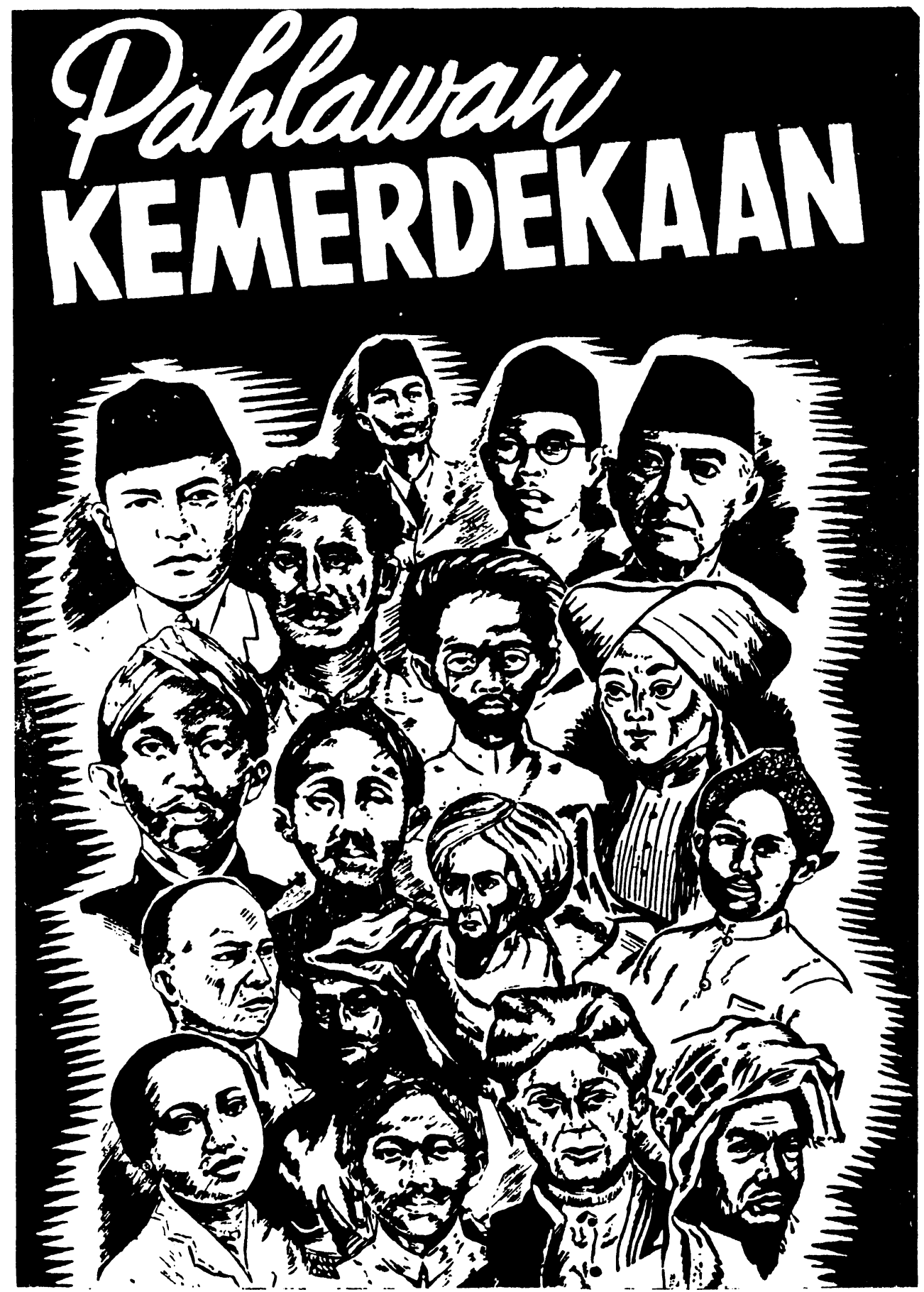

Plate VIII. Reproduction of the Pahlawan Kemerdekaan brochure cover.

This is a 36-page brochure measuring $24 \times 34 \mathrm{~cm}$, written by Nasrun A.S. and D.P. Sati Alim, illustrated by I.T.Man, Ismail Usman and Agus Gardjito, at the request of the Ministry of Information. The preface is dated Djakarta, 10 Nopember 1953, establishing the publication as a contribution to the celebration of Heroes' Day (Hari Pahlawan), which commemorates every November 10 the resistance, in October-November 1945, of the population of Surabaya, to the British occupation of the city. Using a simple narrative underpinned by large illustrated blocks, the authors evoke the struggle of 17 figures against the Dutch occupation: each character, in alphabetical order, is given two pages. The cover, reproduced here, presents a group portrait (see key below): 


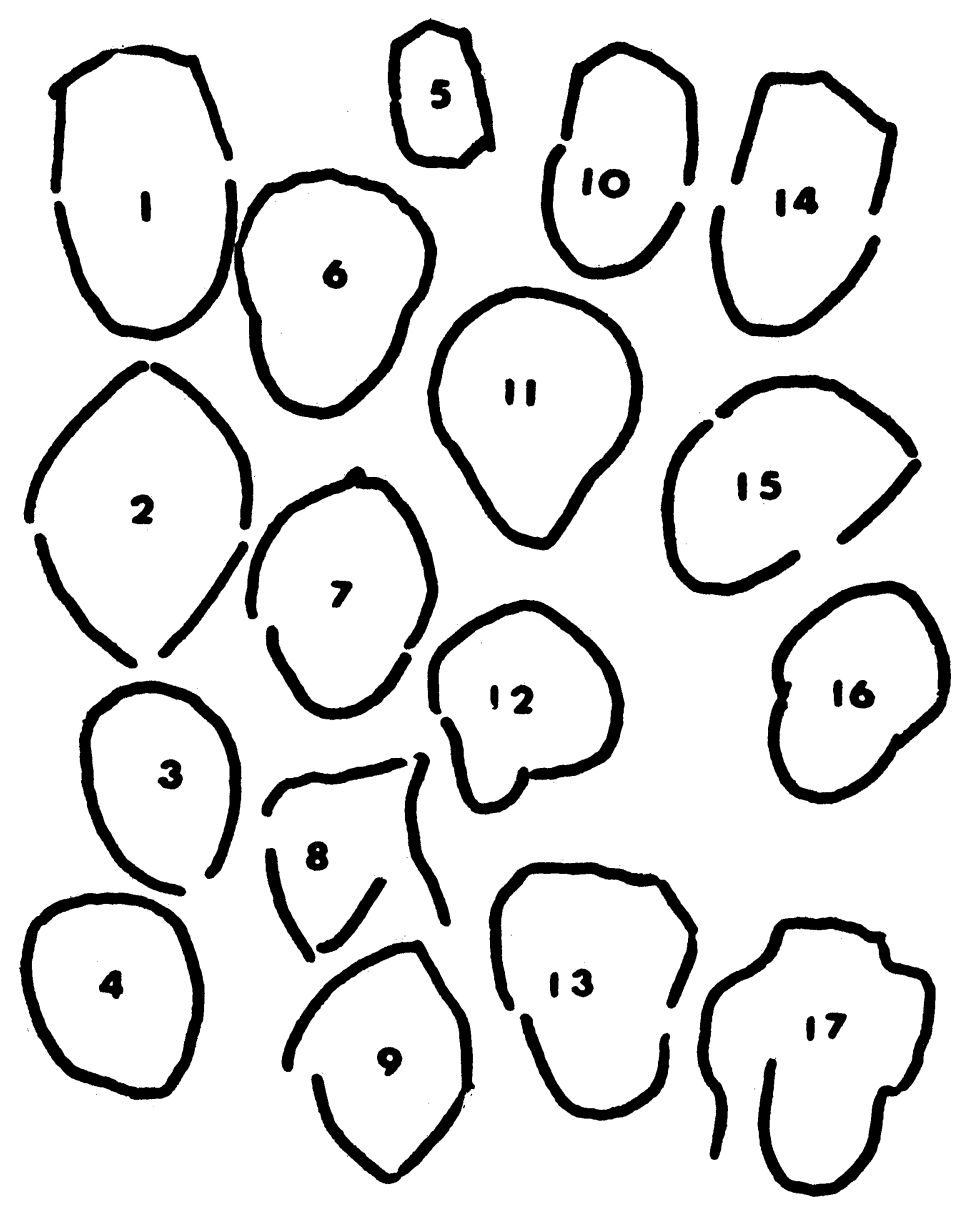

1. M.H. Thamrin; 2. Tjipto Mangunkusumo; 3. G.S.S.J. Ratulangie; 4. R.A. Kartini; 5. Sudirman; 6. Pattimura; 7. Wahidin Sudirohusodo; 8. Sultan Hasanuddin; 9. H.O.S. Tjokroaminoto; 10. W.R. Supratman; 11. K.H. Ahmad Dahlan; 12. Imam Bondjol; 13. Pangeran Hidajat; 14. Setiabudhi (E. Douwes Dekker); 15. Pangeran Diponegoro; 16. R. Sutomo; 17. Thji' di Tiro.

The brochure directly influenced the program of the set also entitled Pahlawan Kemerdekaan, which appeared in 1961 and 1962. Of 12 stamps issued in 1961, 8 featured figures commemorated in 1953, using identical portraits; the other 4 are in memory of, on the one hand, political figures who died after 1953-Abdul Muis, Surjopranoto, and Ki Hadjar Dewantoro (who all died in 1959); on the other, Teuku Umar, a late 19th-century war leader from Aceh. As for the 8 stamps issued in 1962, 5 of the names illustrated had also appeared in 1953, but only Setaiabudhi's portrait is taken from the same source; the portraits of Agus Salim (died 1954), Samanhudi (died 1956), and Singamangaradja (19th century) have been added. Perhaps the four public figures featured in 1953 and dropped from the release program (Hidajat, Supratman, Tjipto, Wahidin) were reserved for a later issue that did not come about (cf. 12 stamps in 1961 and only 8 in 1962). As far as Tipto is concerned, see 7.3. 
legitimates the Javanese Mataram dynasty, whose princely families in Yogyakarta are among the heirs. Sukarno's presence is meant, then, to attach to the person of the head of State the legitimating network that the capacity for founding the signal that reveals it centralizes, in the last instance, in Jakarta. The aim, then, is to inscribe the center, its genealogy and its space, the sovereign and his sovereignty.

Nothing remains of the problematic of the State by the time the "Tourism" sets are issued: tourism as a technique for financing without political intent, without political pedagogy, using the symbolic arrangement of the territory.

6.5 The arms are outstretched; the hands open; the chains that had bound the hands and feet, broken: TUGU SELAMAT DATANG and TUGU IRIAN BARAT echo each other, welcoming those who free themselves, and welcoming those who come, when it is to help us in our struggle for national unification. The couple from the Selamat Datang group of the 1962 Monuments set is greeting the newly arrived guests and, as masters of the house, showing them around the recent improvements in their domain. But, every bit as much as the city, the couple closes the space of time that the archer, like his arrow, had sent flying over the centuries, closing an era of dispossession and renewing the ties between history and the world.

6.6 In the wake of the ongoing public works program in Jakarta, meeting places and signals of dynamism suddenly appear in the space of the stamp, and the Asian Games and GANEFO themselves convoke them, outside and inside, concentration and expression, and the National Monument diffuses their dialectic. A pictoral sign of this relationship, the stamp is inserted into the horizontal thread of the postal network that was to cover the open, many-faceted country, scaling down the center and its monumental axis, the signals that crisscross the cardinal space of the new-world capital, a round trip from the symbolic to the non-symbolic, a representative system.

The mosque, stadium, and hotel, all center monuments, organize the function of a capital, which is not the sovereign's place of residence but the place from which sovereignty is exercised, the measure of the domain and the gathered nation, fragmentation of the palace, ultimate subversion of Borobudur, the public locus of the demonstrations, meetings, and deliberations, the people's ticket to history because it is there that it can be seen, there that others come to see it, and there that the people can receive. A call to rise up, in the civic center, where the festival of nations unfolds.

\section{$7 \quad$ Inventing Time (see pl.VIII)}

7.1 It was for dwiwindu kemerdekaan (see above 4.1.3) that the first portion (4 figures) of a set devoted to "Heroes of National Independence": Pahlawan Kemerdekaan Nasional) was published; the second installment was issued the following October 5 (Army Day, one of the major national holidays); the third was issued November 10, Hari Pahlawan; the fourth, October 5, 1962; the fifth followed on November 10; making, for 1961-62, a collection of twenty public figures. The set was then suspended for what were most likely political reasons; in 1969 it seemed to reappear in a new form (different format, different maquettiste, same face value for all stamps, no connection with national holidays), but this issue of six figures was short lived.

7.2 Until then there had been few heads: two in all, the chief of State and, for the tenth anniversary of the postal service, its first director. But in 1953, we can see the beginnings of a filiation; satriya, the nobleman, the knight, figured on a set of standard values issued in January, and ten years after the battle of Surabaya, a homage to those who died, a cenotaph 
inscribed with HARI PAHLAWAN 10 NOP. 1955. History was no longer anonymous, but these were special selections. ${ }^{14}$

7.3 Two groups of fighters can be read from these issues: on the one hand, those who struggled against colonial expansion from the 17th to the beginning of the 20th century and, on the other, the public figures who, for one reason or another, took part in the national liberation movement proper, after the beginning of the century (see fig. 8-9). If we compare the names on the 1961-62 stamps with those found in various popularized texts or summaries of Indonesian history, we might well wonder if we are not dealing with a closed list, set in its finitude to balance the regions with a view to highlighting the role played by all the peoples of Indonesia, each in its own time, in building the nation. ${ }^{15}$

Of the 13 public figures of the second group featured in 1961-62, 10 are from Java (1 Indo, 1 Jakartanese, 8 Javanese stricto sensu), 2 from Sumatra (Minangkabau), 1 from Sulawesi (Minahasa); 6 can be said to represent the Muslim branch of the national movement (5 for Sarekat Islam, 1 for Muhammadyah), 5 illustrate other national movement tendencies: Setiabudhi (the name later taken by E. Douwes Dekker) and Ki Hadjar Dewantoro (formerly Suwardi Suryaningrat) for the Indian National Party-but Ki Hadjar is better known as the founder of the school system Taman Siswa; Sutomo, Ratulangie, and Thamrin, for the initially regional associations which after 1935 became the Party of Greater Indonesia (Parindra). In a class apart are Kartini, as lone woman of the set and the tutelary figure of Indonesia's feminist movement, and Sudirman, organizer of the Indonesian army, who carries on the tradition of featuring war leaders-picked up once again in the 1969 set with the head of General Gatot Subroto. This selection leaves out figures from the lower classes (e.g. Samin), admitting only representatives of the aristocratic levels of colonial society, heirs to the former principalities or former states, traditional or religious leaders, traditional local dignitaries turned senior civil servants, guardians of an ancestral legitimacy that must be maintained or recovered, representatives of the durability of the Indonesian State through all the vicissitudes of history. That is probably why no leader of any insurrection, such as the national uprising of 1926-27-because such movements demand a new State, a State for the people and not for former princes or new dignitaries-is found in this State Gallery, nor any of those who, even though historically linked with the demands of the dispossessed elites, looked favorably on popular demonstrations: Tjipto Mangunkusumo, for instance, is not among the figures, even if he is generally recognized as one of the fathers of the national movement, of the National Party, inseparable from Setiabudhi and Ki Hadjar: ${ }^{16}$ an absence

\footnotetext{
14 It would be interesting to compare this selection with the nomenclature of the streets of Jakarta since 1950: the central figures of political time as they stand in the central figure of political space, i.e. the center as it is drawn by the governing circles of Indonesia.

15 The leaflet Indonesia, distributed in 1971 by the Indonesian Embassy in France, reads: "Among the Indonesian patriots who opposed and fought the Dutch, we can mention: Thomas Matulessy (Pattimura, Moluccan uprising 1916-18), Pangeran Diponegoro (Java War 1825-30), Tjik di Tiro, Teuku Umar (Aceh War 1873-1903), Tuanku Imam Bondjol (Padri War in West Sumatra 1830-37), Si Singamangaradja (Batak War 1907.)" All these characters were featured on stamps and all were listed-with one or two exceptions-in other widely distributed brochures (see pl. VIII). This political concern with regional balance does not exclude denouncing either Javanese domination (it was claimed, for example by Kahar Muzakar, see above note 7, that the choice deliberately passed over important figures of other islands) or the use of these figures to denature the true meaning of their fight, which was not a fight for Indonesia (the thesis of advocates of the Republic of the South Moluccas, for example; cf. J.A.Manusama, The South Moluccas, Rebellious Province or Occupied State [Leiden, 1960]).

16 Adopting Sukarno's thesis on the tritunggal constituting Indonesian unity, Ruslan Abdulgani, as early as 1952 (see Basic Information on Indonesia [Jakarta: Ministry of Information, 1953], the same year, then, as the brochure shown in pl.VIII) and, once again, Sajuti Melik in 1963 (see Indonesian Political Thinking, p. 372), indicate Tjipto as
} 
Figure 8. Pahlawan Kemerdekaan, 1961-62 (cf. pl. VIII and ch. 7)

\begin{tabular}{|c|c|c|c|c|c|}
\hline & \multirow{2}{*}{ Face value } & \multicolumn{4}{|c|}{ Public figures featured } \\
\hline & & Name & $\begin{array}{l}\text { Official dates } \\
\text { of birth and } \\
\text { death }\end{array}$ & $\begin{array}{l}\text { Ethnic } \\
\text { group }\end{array}$ & $\begin{array}{l}\text { Political } \\
\text { group }\end{array}$ \\
\hline $\begin{array}{l}\text { 1961-62 } \\
\text { maquettes by } \\
\text { Much.Gozjali }\end{array}$ & $\begin{array}{r}0.20 \\
0.25 \\
0.30 \\
0.40 \\
0.50 \\
0.60 \\
0.75 \\
1.00 \\
1.25 \\
1.50 \\
2.00 \\
2.50 \\
\\
3.00 \\
4.00 \\
4.50 \\
\\
\\
\\
5.00 \\
6.00 \\
7.50 \\
1.00 \\
15.00 \\
\end{array}$ & $\begin{array}{l}\text { Abdul Muis } \\
\text { Hasanuddin } \\
\text { Surjopranoto } \\
\text { T.Tjhik di Tiro } \\
\text { T.Umar } \\
\text { Samanhudi } \\
\text { Pattimura } \\
\text { Kartini } \\
\text { A.Dahlan } \\
\text { Imam Bondjol } \\
\text { Singaman-garadja } \\
\text { M.H.Thamrin } \\
\text { Dewantoro } \\
\text { Gen.Sudirman } \\
\text { G.S.S.J. } \\
\text { Ratulangie } \\
\text { Diponegoro } \\
\text { Setiabudhi } \\
\text { Tjokroaminoto } \\
\text { Agus Salim } \\
\text { Sutomo } \\
\end{array}$ & $\begin{array}{l}1886-1959 \\
1631-1669 \\
1872-1959 \\
1831-1891 \\
1840-1899 \\
1868-1956 \\
1782-1817 \\
1879-1904 \\
1868-1923 \\
1772-1864 \\
1846-1907 \\
1894-1941 \\
1889-1959 \\
1912-1950 \\
1891-1949 \\
\\
\\
1785-1855 \\
1879-1950 \\
1883-1934 \\
1884-1954 \\
1888-1938 \\
\end{array}$ & $\begin{array}{l}\text { Minang } \\
\text { Bugis } \\
\text { Java } \\
\text { Aceh } \\
\text { Aceh } \\
\text { Java } \\
\text { Maluku } \\
\text { Java } \\
\text { Java } \\
\text { Minang } \\
\text { Batak } \\
\text { Jakarta } \\
\text { Java } \\
\text { Java } \\
\text { Minahasa } \\
\\
\text { Java } \\
\text { Indo } \\
\text { Java } \\
\text { Minang } \\
\text { Java }\end{array}$ & $\begin{array}{l}\text { S.I. } \\
\text { S.I. } \\
\text { S.D.I. } \\
\begin{array}{l}\text { Muhamma- } \\
\text { diyah }\end{array} \\
\text { Kaum Betawi, } \\
\text { Parindra } \\
\text { Ind. Partij } \\
\text { Persatuan } \\
\text { Minahasa, } \\
\text { Parindra } \\
\text { Ind. Partij } \\
\text { S.I. } \\
\text { S.I. } \\
\text { Parindra }\end{array}$ \\
\hline $\begin{array}{l}1969 \\
\text { maquettes by } \\
\text { Suroso and } \\
\text { Sudirno }\end{array}$ & $\begin{array}{l}15.00 \\
15.00 \\
15.00 \\
15.00 \\
15.00\end{array}$ & $\begin{array}{l}\text { Tjut Nja' Din } \\
\text { Tjut Nja' Meuthia } \\
\text { Dewi Sartika } \\
\text { Gen. Gatot } \\
\text { Subroto } \\
\text { St. Sjahrir } \\
\text { F.L.Tobing }\end{array}$ & $\begin{array}{l}1848-1908 \\
1870-1910 \\
1884-1947 \\
1909-1962 \\
\\
1909-1966 \\
1899-1962\end{array}$ & $\begin{array}{l}\text { Aceh } \\
\text { Aceh } \\
\text { Sunda } \\
\text { Java } \\
\text { Minang } \\
\text { Batak }\end{array}$ & P.S.I. \\
\hline
\end{tabular}

Note: S.D.I.: Sarekat Dagang Islam; S.I.: Sarekat Islam; P.S.I.: Partai Sosialis Indonesia; Ind. Partij: Indische Partij (but Dewantoro and Setiabudhi are names taken after the party's dissolution by the people represented, which means that party affiliation is not a determining criterion in this case).

In italics: the names of war leaders, indicated by a circle on the map in figure 9.

The distribution of face values on the 1961-62 stamps does not seem to indicate any ideological choice: there does seem to have been a problem, however, since the stamps of the 1969 set (like those of the 1966 "Victims of October 1, 1965," issued in 1966) all have the same face value. It may also be considered that the choice of the three men featured in 1969 is tied to their birthdays.

personifying the Nasional branch, alongside the Islam (H.O.S. Tjokroaminoto) and Komunis (Semaun) branches: of the three, only Tjokroaminoto, in the 1961 and 1962 sets, is given his painting. 
Figure 9. The "Heroes of independence" selected for 1961, 1962, and 1969 (geographic origin and typology by sex and main activity)

Key

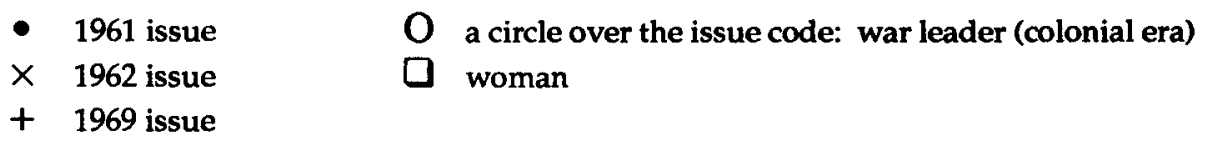

We see that out of 26 public figures mentioned, 10 come from Sumatra, 12 from Java (a 13th sign, on Java, indicates the Eurasian E. Douwes Dekker, alias Setiabudhi Danudirdjo) and that, of the 13 from outside Java, 8 represent the princes' resistance to colonial penetration, whereas the national liberation movement leaders are concentrated on Java.

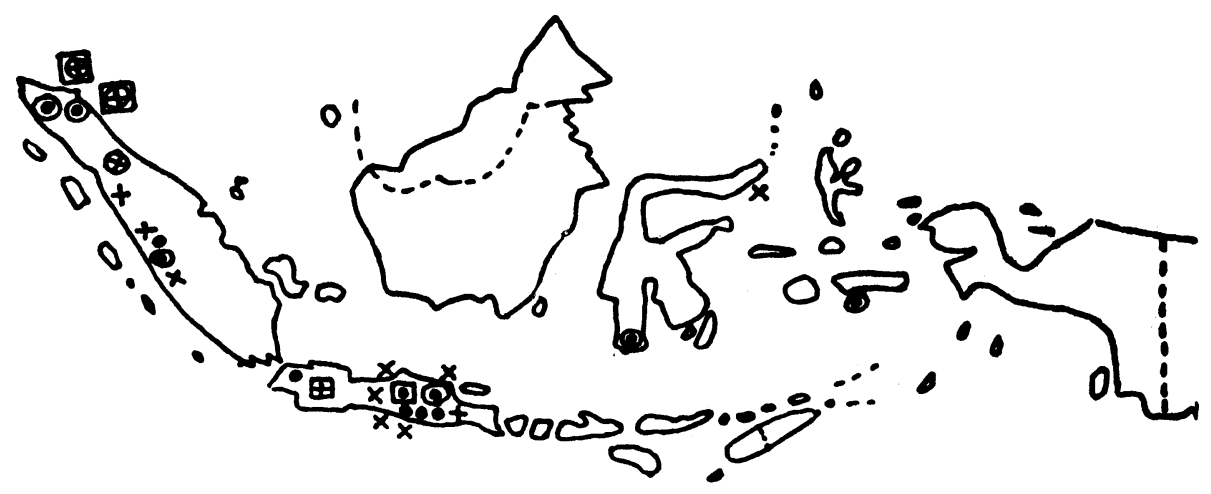

Fig.10. Curiosities, tourism, and taking possession of the space

\section{Key}

Sets with a background map showing the subject's place of origin

由 wild animals, 1958

$\$$ musical instruments, 1967

$\varnothing$ tourism on Bali, 1969

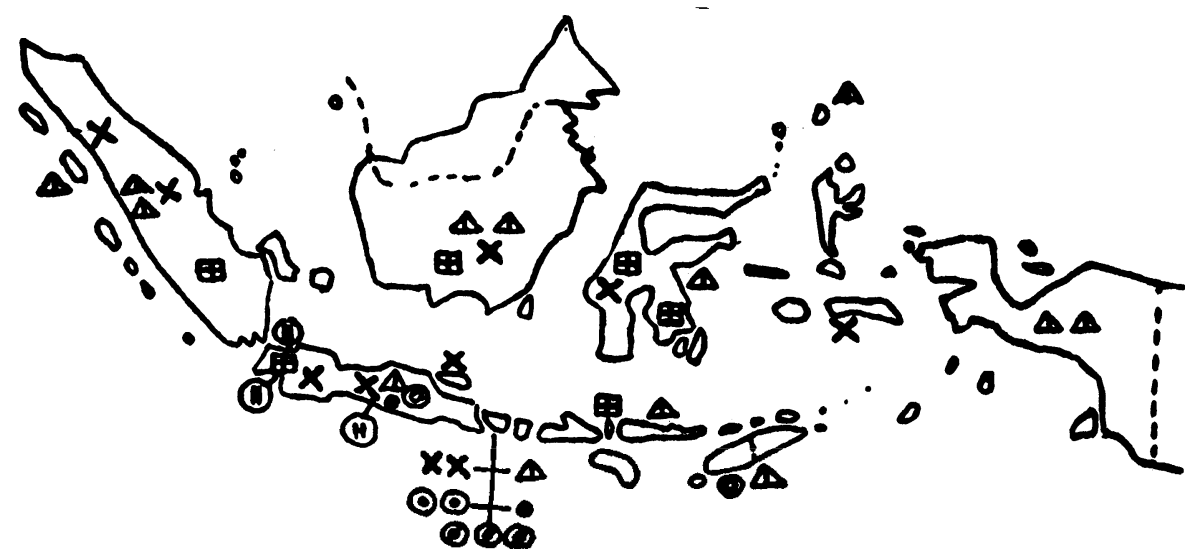

Sets with no background map

H major hotels, 1962, 1965 (cf. pl.V)

$\times \quad$ The Year of the Orient, 1961

- 12th Conference of the Pacific Area Travel Association, 1963

(.) tourism, set issued yearly from 1967

Already in 1938, one of the creators and masters of Indonesian painting, Sudjojono, urged his colleagues to wake up to the fact that Indonesia had more to offer than just landscapes; there were events, even though, we would add, a landscape may be an event, as the Impressionists proved. Now what characterizes the event in this case is that it has become nothing more than a landscape, a monument, that is, a memory, diluted in the stereotyping of voyage and cruise, for which the bloody history of peoples is only an exotic breeze. And yet, such cries as "Save Borobudur" and "Lindungilah Margasatwa" sometimes recall that this landscape, too, is history and may die.

Because the "Tourism" set mentions places, festivals, products, a specified environment, it also fulfills the function of teaching about the territory, sometimes using a map for more detail; this territory can be compared with the version provided by the Pahlawan set (fig.9). Madura has been credited with one 1961 stamp (Year of the Orient) marked "Bull Race," bearing no place name; the location of the other subjects mentioned heremonuments, sites, dances, objects -is either printed on the stamp or is obvious. Those stamps valid only on Irian are not indicated (cf. pl. VI). 
perhaps due to the interruption of the set, or, more likely, to Tjipto's interest in Saminism and communism (he was arrested following the 1926-27 uprisings), and to his hostility to fascism and the Japanese.

This lesson taught by a history that extends from princely resistance to prefectural government can be found again in the 1969 set, with one new development: half of the figures are women (cf. fig. 9), an advance that can be linked, with respect to the preoccupations of those responsible for the release programs, to the issue some weeks later of a small figure in honor of "Women's Emancipation" (Kebangkitan wanita); and while one of these women, Dewi Sartika, was the founder of the first schools for girls in Indonesia (in Bandung), the men, S. Sjahrir (whose appearance is a sign of his political rehabilitation after the repression he underwent under Guided Democracy) or F.L.Tobing, were administrators whose audience vanished as soon as they left the halls of power. If the ethnic range of the six figures for 1969 is remarkably broad-Acehnese (Tjut Nja' Din, represented for Aceh, together with Tjut Nja' Meuthia, was the wife of T. Umar; cf. pl. VIII), Batak, Minangkabau, Sundanese, Javanese-the political range had not changed: there were the civilian governor (Tobing), the military governor (Gatot), the head of the government (Sjahrir); it was a question of formulating neither political ideas nor activities, but the machinery of the State.

7.4 It was the State that designated territorial alliances, legitimation by history defined by the succession of ancestors: the quest for one's name. The postal service inaugurated the process when it presented, in 1953, its headquarters, and in 1955, its founder, an umbilical collusion between space and time; in 1966-67, Sukarno's end was inscribed in two sets, one of which spelled out the ten soldiers killed in the Untung coup; the other of which published the maquette of the monument raised on the spot where the bodies had been found, the center of a new pilgrimage that instituted a new regime.

\section{The Flow of the Meaning}

8.1 The stamp-tax and relationship figure-outlines a flow space, within which a circulation takes place, that is at the same time an area within which meaning is diffused: between 1958 and 1963, in the main, it exhibited proof of the convergence of a name, a territory, a kinship, duration and legitimacy of a State.

8.2 The stamp built a capital, the fusion of the center and the space, of the name and the named, of the inside and the outside. The capital organized the environment and summoned it, faces from the past, statues of the future, the making of motion and progress. If crowds came, they were regaled with celebrations that called the country by its name and engraved it in the memory of its own and other peoples. Indonesia came to the capital to see itself, to look at itself, to hear itself, in other words to come together, to make acquaintance, and to unite: to recognize each other as brothers living in the same house.

8.3 A people needs education over and above all other rights, and the State alone has a voice, with which it identifies the nation and provides it with a body.

8.4 But the civic center soon gave way to the business center and the deposed monument became a site with no memory, good for providing the commerce of the named with universals. The symbol was subverted. Bali had won. 